\title{
Health and Heating in the City of Temuco (Chile). Monetary Savings of Replacing Biomass with PV System in the Residential Sector
}

\author{
José M. Cansino ${ }^{1,2, *(\mathbb{C})}$, Roberto Moreno ${ }^{3}\left(\mathbb{D}\right.$, Daniela Quintana ${ }^{4}\left(\mathbb{C}\right.$ and Rocio Roman-Collado ${ }^{1,2}{ }^{(1)}$ \\ 1 Faculty of Economic and Business/Department of Economic Analysis and Political Economy, Universidad de \\ Sevilla, Avda. Ramón y Cajal 1, 41.005 Sevilla, Spain; rroman@us.es \\ 2 Universidad Autónoma de Chile, Avda. Pedro de Valdivia, 425, Providencia, Santiago 7500912, Chile \\ 3 Centro de Investigación Multidisciplinario de La Araucanía (CIMA), Universidad Autónoma de Chile, Avda. \\ Alemania No. 01090, Temuco 4780000, Chile; roberto.moreno@uautonoma.cl \\ 4 Centro de Investigación Multidisciplinario de La Araucanía (CIMA), Facultad de Arquitectura y \\ Construcción, Universidad Autónoma de Chile, Avda. Alemania No. 01090, Temuco 4780000, Chile; \\ daniela.quintana@uautonoma.cl \\ * Correspondence: jmcansino@us.es; Tel.: +34-954557528
}

Received: 26 August 2019; Accepted: 20 September 2019; Published: 23 September 2019

\begin{abstract}
The paper conducts a comprehensive analysis of replacing residential use of wood burning stoves for heating with photovoltaic systems for the generation of electricity using storage batteries (PV + storage systems). The research focuses on the city of Temuco (Southern Chile) as a case study, since this city has a high use of firewood for heating ( $80 \%$ of households) and also because this city has been declared by authorities as an area saturated with suspended particles. The total cost corresponds to the acquisition of systems. The reduction of monetary value of the impact of polluting emissions, resulting from the combustion of firewood, on health and traffic accidents is calculated. The interactive tool GDB Compare has been used to calculate the impact of pollution on health both in terms of attributable deaths and disability-adjusted life years. The monetary value of the impact on health has been calculated using two alternative approaches: the value of statistical life and the human capital approach. To identify firewood use requirements, heating degree-days has been used for temperatures $\leq 15{ }^{\circ} \mathrm{C}$ and $\leq 18{ }^{\circ} \mathrm{C}$. The emissions avoided calculations have been refined, including emissions associated with the manufacture and transport of systems through the life cycle analysis. For all scenarios, the main results show that the savings outweigh the costs.
\end{abstract}

Keywords: ambient particulate matter; household air pollution; Temuco; DALY

\section{Introduction}

The residential sector in Chile is highly intensive in the use of firewood for heating. In the mid-1990s, $85 \%$ of urban households consumed firewood [1]. Currently, $80 \%$ of households in the city of Temuco, in which this article is focused, use wood for heating [2]. In 2013 (latest data available), the total consumption of firewood in Chile was 56,219.5 teracalories (Tcal), of which $62.6 \%$ corresponded to the residential sector [3]. To meet this demand, 10,074.1 tons of firewood were required, causing environmental stress on the Chilean forest area, acting against a sustainable model to meet a comfortable standard of living in the residential sector. This area represents $22.9 \%$ of the total area of the country (17.3 million hectares) and acts as a large greenhouse gas (GHG) emission sink [4] to sustainability. However, it might be borne in mind that the pressure on the forest is also due to its use as fodder and not only the extraction of firewood. 
Smith [5] offered an interesting panoramic view of the negative impact of air pollution on health, pointing out that the use of wood for heating homes had a negative impact on health and road safety. In addition to $\mathrm{CO}_{2}$ emissions, the incomplete combustion of solid biomass for heating (mainly firewood) emits basically carbon monoxide, but also benzene, butadiene, formaldehyde, polyaromatic hydrocarbons, and many other compounds hazardous to health. Among these other compounds are suspended particles [5-7].

The basic evidence on health effects from particulate matter is summarized by [8]. This literature offers interesting case studies focused on illnesses caused by ambient particulate matter pollution $[9,10]$. Both together-household air pollution from fossil fuels and ambient particulate matter pollution-act as risk factors of ischemic heart disease, stroke, tracheobronchial and lung cancer, lower respiratory infections, chronic obstructive pulmonary disease, and diabetes mellitus.

Their impact on health can be assessed measuring the number of attributable deaths. Alternatively, it can be assessed measuring the number of disability-adjusted life years (DALYs) caused by these risk factors on the population. One DALY can be thought of as one year of "healthy" life lost. The monetary value of attributable deaths or DALYs caused reveals useful information for better design of mitigation and health policies in terms of resource allocation.

Additionally, in areas exposed to the meteorological phenomenon denominated as thermal inversion, air pollution (mainly ambient particulate matter) increases the risk of traffic accidents. Thermal inversion is a meteorological phenomenon associated with the presence of high mountains that surround a city and low temperatures in winter.

Thermal inversion traps air pollution, such as smog, close to the ground. This occurs in cities like Temuco (W72 $\left.35^{\prime} 54.31^{\prime \prime}, S^{\circ} 38^{\circ} 44^{\prime} 22.74^{\prime \prime}\right)$, in the south of Chile, with around 265,000 inhabitants. Environmental pollution in Chile is a problem that affects all of the South-Central area of the country. The policy context is important to better understand the proposal made in this paper. The Decontamination Plans have been the main measure developed in Chile. The Chilean authorities assume that the atmospheric contamination is a first-level challenge. The Ministry of the Environment [11] estimates that 10 million Chileans are exposed to a level of atmospheric contamination of PM 2.5 above that allowed in the air quality standard. The current Atmospheric Decontamination Plan falls within the so-called Strategy of Atmospheric Decontamination Plans 2014-2018. In the case of the plans of the south of the country, given that the main contaminating source is the use of firewood for heating, the strategy is oriented towards fostering sustainable heating. The main actions are aimed at diversifying the energy matrix of home, business, and public heating. For cases such as the city of Temuco, the Decontamination Plan considers two structural measures: 1) the thermal conditioning of homes, and 2) the substitution of contaminating heating systems by efficient systems that have less emissions [12]. Our proposal is to be found in this second measure. Together with Decontamination Plans, another ambitious measure developed so far in the Chilean residential sector has been the so-called "Heater Replacement Program" [13]. This program focused on changing firewood for pellets and kerosene. The program implements a co-payment for the beneficiary who, in addition, must deliver to the Ministry of the Environment the firewood device that is being replaced so that it can be destroyed.

The Chilean authorities classify their territory into seven different thermal zones. The zone number increases in line with the heating requirements so that homes reach a comfort standard of $20^{\circ} \mathrm{C}$. Temuco belongs to thermal zone 5, which identifies it as a city subject to cold weather [14].

Due to the emission of pollutants caused by combustion, the substitution of firewood for heating with non-polluting alternative systems would be beneficial both for health and road safety. Recently, the Chilean 20.571 Netbilling Act has facilitated the installation in the residential sector of electric self-generation systems based on nonconventional renewable energies (NCRE).

The most widespread technology at the market level consists of the use of photovoltaic solar panels (PV). The energy generated by these panels can also be partially stored in batteries installed in the home (PV + storage). This facilitates replacement of domestic wood burning stoves with PV + storage systems, avoiding pollutant emissions from wood combustion associated with heating. Figure 1 
illustrates how a PV + storage system replaces the use of a wood burning stove, thus, reducing the emission of pollutants.

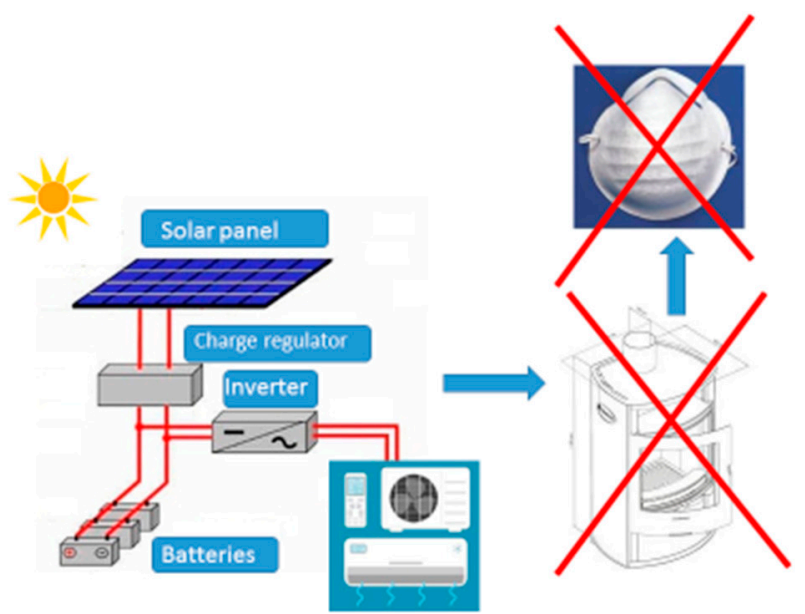

Figure 1. Replacing wood stoves with a photovoltaic system (PV) for the generation of electricity using storage batteries (PV + storage) system.

The aim of this paper is to assess monetary saving on illness and traffic accidents due to replacing domestic wood burning stoves for heating with domestic pollutant emission-free PV + storage systems. Monetary savings derive from the mitigation of pollutant emissions due to the reduced burning of wood, the reduced deforestation, and the decreases in both health damage and traffic accidents. When calculating benefits, $\mathrm{CO}_{2}$ emissions stemming from manufacturing and transport might be considered [15].

Therefore, the impact of air pollution from fossil fuels and ambient particulate matter on health is assessed taking DALYs and attributable deaths as the central topics from the output provided by the interactive tool GDB Compare [16]. The monetary value is calculated by following two complementary approaches; the value of statistical life and the human capital approach. Due to availability of data, 2013 is used as the reference year.

Despite the use of DALYs in the field of Health Economics, its use in fields such as Environmental Economics or Energy Economics has been limited; thus, this is one of the novelties of this paper. To the best of our knowledge, no previous research exists conducting a similar analysis of introducing clean nonconventional technology (PV + storage systems) replacing the conventional use of biomass for heating based on the health impact and the absence of $\mathrm{CO}_{2}$. This paper contributes to filling this gap in the literature. Additionally, this paper does not adopt the assumption of extensive literature establishing biomass combustion as neutral in terms of $\mathrm{CO}_{2}$. Alternatively, we use a specific emissions factor for firewood combustion and a lower factor for establishing $\mathrm{CO}_{2}$ through photosynthesis.

\section{Materials and Methods}

A description of the PV + storage system is provided in Section 2.1. After this, a method used for the monetary valuation of health damage is described. This section ends by explaining the monetary valuation of emissions avoided. Data sources are also detailed before the results.

\section{1. $P V+$ Storage System Characteristics}

The PV systems installed in houses feed electrically driven heat pumps. The system is optimised when batteries are incorporated to store the electricity generated but not consumed instantaneously (Figure 1). When this replacement is made in a house, emission of pollutants derived from the combustion of firewood is prevented. However, due to installation requirements, not all homes enable the installation of a standard PV + storage system. 
Additionally, it must be taken into account that when the surface area of the house is very large, the heating capacity of a standard PV + storage system may be insufficient. Currently the most widely used is Solar Kit $5000 \mathrm{~W}, 48 \mathrm{~V}$, with a capacity to generate 16,000 kWh/day. The main characteristics are summarized in Table 1. A lifetime of 20 years is assumed.

Table 1. Standard PV + storage system.

\begin{tabular}{|c|c|c|c|c|}
\hline & Characteristics & $\begin{array}{l}\text { Unit Cost } \\
\text { (USD 2013) }\end{array}$ & $\begin{array}{l}\text { Number of } \\
\text { Units Required }\end{array}$ & $\begin{array}{l}\text { Total Item Cost } \\
\text { (USD 2013) }\end{array}$ \\
\hline Solar panel & $\begin{array}{c}\text { polycrystalline } 330 \mathrm{~W} \\
24 \mathrm{~V}, 1956 \mathrm{~mm} \times 992 \\
\mathrm{~mm} \text {, cell efficiency } \\
17.01 \%, 20 \mathrm{~kg} \text { in weight }\end{array}$ & 343.4 & 10 & 3434.3 \\
\hline $\begin{array}{l}\text { Inverter charger + } \\
\text { regulator }\end{array}$ & $58 \mathrm{~kg}$ & & & 2222.2 \\
\hline Batteries & $\begin{array}{c}\text { ROLLS } 12 \mathrm{~V} \text { lead acid } \\
360 \mathrm{Ah}: 60 \mathrm{~kg} \text { in } \\
\text { weight }\end{array}$ & 888.8 & 8 & 7111.1 \\
\hline Structure & & & & 303.0 \\
\hline $\begin{array}{l}\text { Cables for photovoltaic } \\
\text { systems and accessories }\end{array}$ & $\begin{array}{l}1 \text { distributor and panel } \\
\text { junction box }\end{array}$ & & & 707.0 \\
\hline $\begin{array}{l}\text { Annual Operation and } \\
\text { Maintenance (O\&M) cost }\end{array}$ & & & & 3726 \\
\hline Total Cost & & & & $14,150.3$ \\
\hline
\end{tabular}

Source: $[17,18]$.

The PV + storage system chosen for this research took into account specific characteristics of the city of Temuco. The optimal number of panels is determined by applying Equation (1):

$$
\text { Number of PV panels }=\frac{\text { Energy consumption } \times \frac{\text { Week days in force }}{7}}{P S H \times \mu \times \text { Installed capacity per panel }}
$$

where energy consumption is the total electricity consumption required by the heating splits. We assume 2 splits per home working 6 hours per day during the whole week. PSH represents the peak solar hours. Following the tool provided by the Chilean Department of Energy [15], the global climbed annual radiation for the city of Temuco is $4.71 \mathrm{kWh} / \mathrm{m}^{2} /$ day. As colder months register low values, the storage system allows for bridging of this issue. The PSH for autumn and winter months varies from 4.81 (March) to 1.56 (June). Table A1 in Appendix A detailed the PSH for the city of Temuco per month and per hour of the day. $\mu$ is the loss coefficient. We assume a value of 0.6 , meaning $40 \%$ of losses because of panels, inverter device, batteries, and accumulators.

The optimal number of batteries is determined by Equation (2):

$$
\text { Number of batteries }=\frac{\text { Energy consumption } \times \text { days }}{\text { DoD } \times \text { tense }} \times(1+\text { loss coefficient })
$$

where 5 days of use of batteries are considered. Tables A2 and A3 contain data of shadow and clouds in the city of Temuco for months and daily hours. DoD is the depth of discharge for batteries $(50 \%$ in the case of lead batteries), the tense assumed is $12 \mathrm{~V}$, and a $15 \%$ loss coefficient is taken into account.

The PV + storage system is switched on when outside temperature falls under $18^{\circ} \mathrm{C}$ or $15^{\circ} \mathrm{C}$. These cold days are the so-called heating degree-days (HDDs). The technical requirements for the installation and its heating capacity make it optimal for homes whose habitable surface area varies between 51 to $70 \mathrm{~m}^{2}$. The number of Temuco homes included within this range is 12,388, representing $41.7 \%$ of total housing. The HDD is a measurement designed to quantify the demand for energy needed to heat a building. The HDD is derived from measurements of outside air temperature. We 
assume that standard comfortable heating is necessary when the outside air temperature falls below 18 or 15 degrees Celsius. Both levels of temperature are considered in order to provide a sensitive analysis.

\subsection{Monetary Valuation of Health Damage}

The interactive tool GDB Compare provides information on two types of health damaging pollution. These are household air pollution from fossil fuels and ambient particulate matter pollution. We assume that firewood combustion causes indoor $\mathrm{CO}_{2}$ emissions that must be considered as part of "household air pollution from fossil fuels"; despite the fact that firewood is not a fossil fuel, it acts as an energy resource similar to other fossil fuels. Together with firewood combustion, it causes ambient particulate matter pollution.

The disability-adjusted life year (DALY) together with attributable deaths are two extensive health gap measures. The DALY concept was jointly developed for the Global Burden of Disease (GBD) study by the World Bank, the Harvard School of Public Health, and the World Health Organization (WHO) in the late 1980s [19-23]. DALY measures both mortality and morbidity and combines them into one single figure providing an evidence-based tool for healthcare policy prioritization and for monitoring intervention effects [24]. The interactive tool GDB Compare provides information for an extensive list of risk disease factors in terms of DALYs and attributable deaths [16].

Several studies [25-27] detail the methods for calculating the monetary valuation of health impacts from risk factors. The literature available offers two main methods that can be used to value health impact in monetary terms. The first is based on the willingness to pay (WTP) for a statistical life year. This relies on asking for the maximum amount of money an individual would be willing to give up in order to avert the loss of a year of life. The WTP approach is also named as the criterion of the value of statistical life (hereafter, VSL). VSL is a measure of the cost of mortality derived from the aggregation of the individual willingness to pay (WTP) in a society $[10,28]$.

This takes into account the number of deaths attributable to a risk factor. VSL is a narrow approach to the consequences of a risk factor on health. The interactive tool GDB Compare provides its output not only in terms of DALYs by risk factor, but also in terms of deaths attributable to different risks. Consequently, deaths attributable to ambient particulate matter pollution and household air pollution from solid fuels are also valued in economic terms by gender by multiplying them by the VSL value for Chile up to 2013, as Equation (3) details:

$$
\text { Monetary valuation VSL approach } \left.=\sum_{i=1}^{5}\left(G B D_{i} \times \omega_{j} \times R_{j} \times P \times V S L\right)\right)
$$

where $\mathrm{GBD}_{\mathrm{i}}$ measures the GBD attributable to i (ischemic heart disease, stroke, tracheobronchial and lung cancer, lower respiratory infections, chronic obstructive pulmonary disease, and diabetes mellitus. $R_{j}$ is the risk factor of pollutant $j$ (ambient particulate matter pollution and household air pollution from fossil fuels). P is the population of the city of Temuco in 2013 and VSL is measured in USD 2013.

The second method of calculating the monetary valuation is lost output or the human capital approach (HCA). By measuring an individual's yearly economic contribution as the GDP per capita, years lost due to disability or death are years that are not productive. Following the HCA approach, the monetary value of DALYs is calculated by multiplying a standardised GDP value per capita by the total number of DALYs. DALYs are the sum of the years of life lost due to premature mortality in the population and the years lost due to disability for incidents of disease or health conditions [29]. This approach was criticised in the literature [26]; thus, a refined version of HCA considering health expenditure provides more specific findings. This is our second approach estimating the monetary value of diseases caused by ambient particulate matter pollution and household air pollution from 
fossil fuels. In this case, we multiply the number of DALYs per GDP net health expenditure per capita in Chile (both current and capital) measured in USD 2013, as Equation (4) shows [27].

$$
\text { Monetary valuation } H C A=\sum_{i=1}^{5}\left\{\left(G B D_{i} \times \omega_{j} \times R_{j} \times P\right)\left[G B P_{p c}-\left(C H E_{p c}+K H E_{p c}\right)\right]\right\}
$$

where GDP $\mathrm{pc}$ being the Chilean gross domestic product per capita in 2013, $\mathrm{CHE}_{\mathrm{pc}}$ the Chilean current health expenditure per capita, and $\mathrm{KHE}_{\mathrm{pc}}$ the Chilean capital health expenditure per capita. All of the monetary variables are measured in USD 2013.

Both criteria described above must be used with caution, not attributing all fossil fuel emissions and ambient particulate matter to the combustion of firewood. To determine the portion of energy consumption of Chilean households corresponding to firewood, the climatic diversity of the country must be taken into account. An exhaustive analysis was based on a sample of urban households corresponding to three cities: Metropolitan Area (zone 2), Valparaiso (zone 3), and Concepción (zone 4) [30]. This last city is the most similar to the climate of Temuco (zone 5) [14]. For the city of Concepción, $51 \%$ of energy consumption in a typical dwelling was for heating ( $4776 \mathrm{kWh} /$ year) [30]. The source was firewood. We conservatively assumed that $51 \%$ of the impact on health caused by household air pollution from fossil fuels is due to combustion of firewood. This corresponds with $\omega_{2}$ in Equations (1) and (2).

Regarding the portion of impact on health that corresponds to ambient particulate matter emitted by the combustion of firewood, the averages for PM2.5 emissions due to this combustion (94\%) and PM10 emissions (82\%) [2] have been considered. This corresponds with $\omega_{1}$ in Equations (1) and (2).

Finally, as ambient particulate matter pollution also increases traffic accidents in cities like Temuco due to thermal inversion, a monetary valuation of victims is carried out. The authorities of Temuco requested that this city be declared as an area saturated with ambient particulate matter and, thus, PM10 was recognised in 2005 and PM2.5 in 2013 [2,28]. In 2018, the Air Decontamination Plan for PM 2.5 took effect.

The monetary values of car accidents was estimated by multiplying the number of victims in the city of Temuco attributable to ambient particulate matter pollution by internal and external cost [30-32]. The authors distinguished between fatalities, serious injuries, and minor injuries. They also differentiated between internal and external costs. Internal costs include medical expenses, material damage, and also WTP for reducing the risk of accidents. External costs include property damage to third parties, health care expenses, police expenses, administrative and judicial expenses, and the current net value cost to the state treasury for loss of contributions of the victims. Equation (5) was used to calculate the monetary values of car accidents

$$
\text { Monetary values of traf fic accidents }=\left\{\left[\sum_{i=1}^{3} \text { Damaged }_{i} \times(\text { Int costs }+ \text { Ext costs })\right]\right\} .
$$

The number of damaged in Equation (5) includes fatalities, serious injuries, and minor injuries. Both internal and external costs are measured in USD 2013 from [33].

\subsection{Monetary Valuation of Emissions Avoided}

Due to its greater accessibility, the type of firewood most used in the city of Temuco is eucalyptus firewood. Emission factors have been assigned to calculate $\mathrm{CO}_{2}$ emissions and ambient particulate matter. The emission factors for eucalyptus firewood is 129.1 grs $\mathrm{CO}_{2} / \mathrm{kg}$ and 10.9 grs PM10/kg [34]. The operation condition considered in the paper to determine the emission factor assumes that the combustion is done with a half and closed chimney flue. The type of firewood considered was dry firewood (Hd. b.s. $<25 \%)$. To determine the heat capacity of the wood, its density $\left(520 \mathrm{~kg} / \mathrm{m}^{3}\right)[35,36]$ and electricity generation capacity $(4.6 \mathrm{kWh} / \mathrm{gr})$ [37] were considered. 
The heating needs of households were calculated based on the HDD approach. Wood requirements for heating are different depending on the size of the home considered. This paper analyses the housing of Temuco, classifying it in a range from dwellings with an area of less than $35 \mathrm{~m}^{2}$ to those with a surface area of more than $140 \mathrm{~m}^{2}$ (see Table A9 in the annex).

Along with the polluting emissions derived from the combustion of firewood, the felling of trees required to supply the firewood reduces the capacity of the forest surface area to act as a sink. To calculate the amount of $\mathrm{CO}_{2}$ not fixed due to the felling of eucalyptus, its fixation rate was used. This factor was $3.67 \mathrm{grs} \mathrm{CO}_{2} / \mathrm{kg}$ [34].

This approach is different from what the literature usually indicates. It is normally considered that the combustion of biomass is neutral in terms of emissions, given that the $\mathrm{CO}_{2}$ emitted is equivalent to that fixed by photosynthesis [38]. In this paper, we used a burning emission factor $\left(129.1 \mathrm{grs} \mathrm{CO}_{2} / \mathrm{kg}\right)$ greater than the fixation rate for photosynthesis $\left(3.67 \mathrm{grs} \mathrm{CO}_{2} / \mathrm{kg}\right)$. This methodological approach is more stylised than that usually used in literature and better expresses the effect of environmental stress caused by the felling of trees for use as firewood for heating. Our approach is in line with the fact that in 2002 the region of Araucanía (region IX of Chile, to which the city of Temuco belongs) lost its status as a net sink due to the significant forest area lost as a result of fires [39].

The installation of PV + storage systems enables calculating emission reduction by comparing two scenarios. The baseline scenario considers that $80 \%$ of households included in the surface area range of 51 to $70 \mathrm{~m}^{2}$ use wood burning stoves with eucalyptus (Eucalyptus globulus) as firewood [40]. In the final scenario, it is assumed that $100 \%$ of these households replace the stoves with PV + storage systems, avoiding pollutant emissions. By comparing the total emission volume of both scenarios, it is possible to calculate emission reduction coefficients (both household air pollution from fossil fuels and ambient particulate matter). These reduction coefficients will reduce the economic value of the impact of polluting emissions on health and traffic accidents.

$$
\begin{gathered}
\mathrm{CO}_{2} \text { Reduction coefficient }=\frac{H_{51-70} \times F_{i} \times H D D_{i} \times\left(\mathrm{CO}_{2} \text { emited }- \text { unfixed } \mathrm{CO}_{2}\right)}{H_{T} \times F_{i} \times H D D_{i} \times\left(\mathrm{CO}_{2} \text { emited }- \text { unfixed } \mathrm{CO}_{2}\right)} \\
\text { PM Reduction coefficient }=\frac{H_{51-70} F_{i} \times H D D_{i} \times\left(\mathrm{PM}_{\text {emited }}\right)}{H_{T} \times F_{i} \times H D D_{i} \times\left(P_{\text {emited }}\right)} .
\end{gathered}
$$

A stylised analysis of avoided $\mathrm{CO}_{2}$ emissions requires a calculation of the $\mathrm{CO}_{2}$ emissions associated with the manufacture, transport, and installation of PV + storage systems using life cycle analysis (LCA) [41-43]. The Results section details the LCA.

Figure 2 summarises the main sequence of methodological steps described above. 


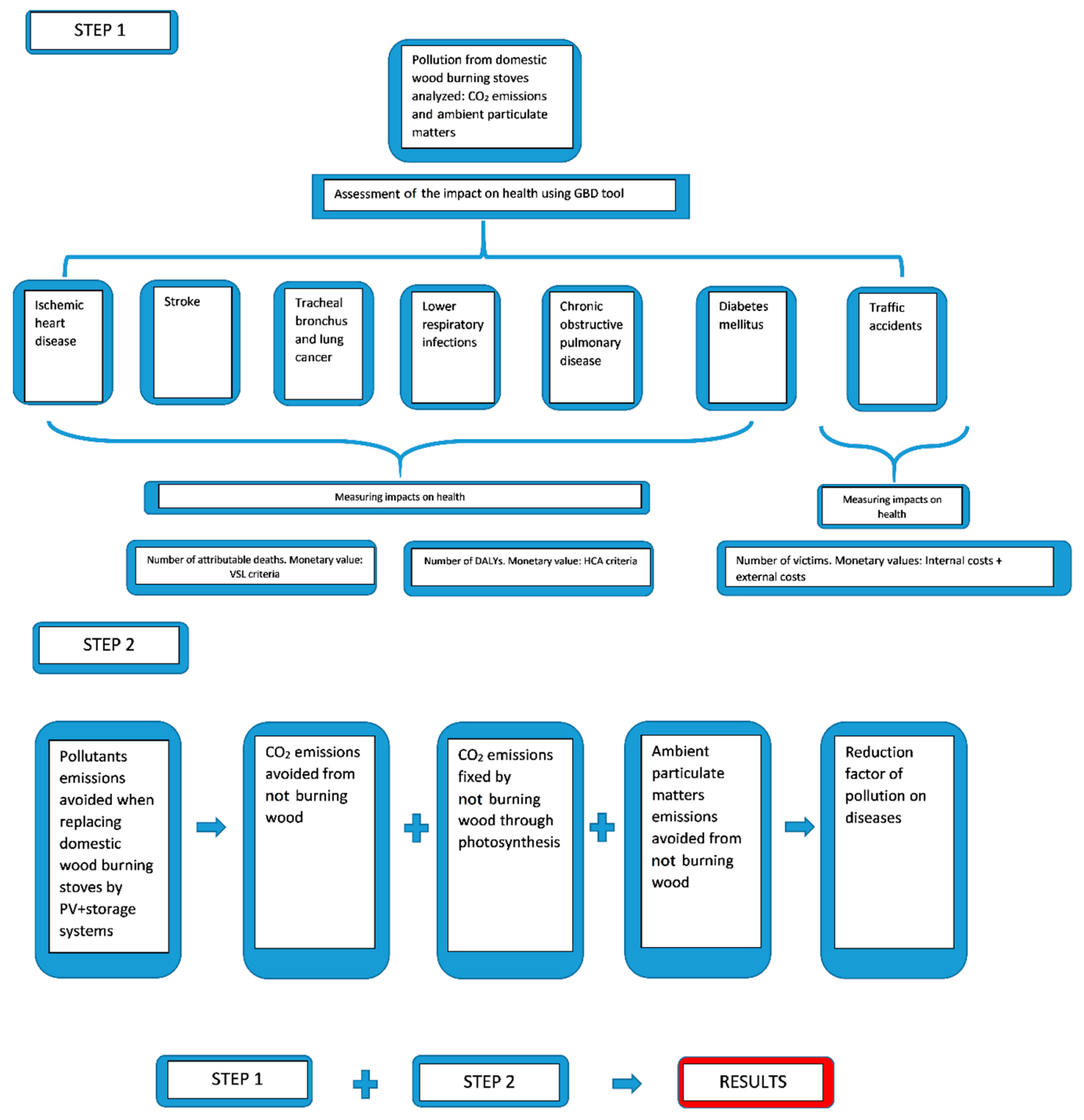

Figure 2. Main sequence of methodological steps

\subsection{Data}

The data on the consumption of firewood in Chile were taken from the national energy balances that provided this data until 2013. As of that year, the series is interrupted, with no data provided for subsequent years despite having been requested. For the period 1991-2013, Figure 3 shows that the trend of wood consumption in Chile was growing and was linked to population growth. 


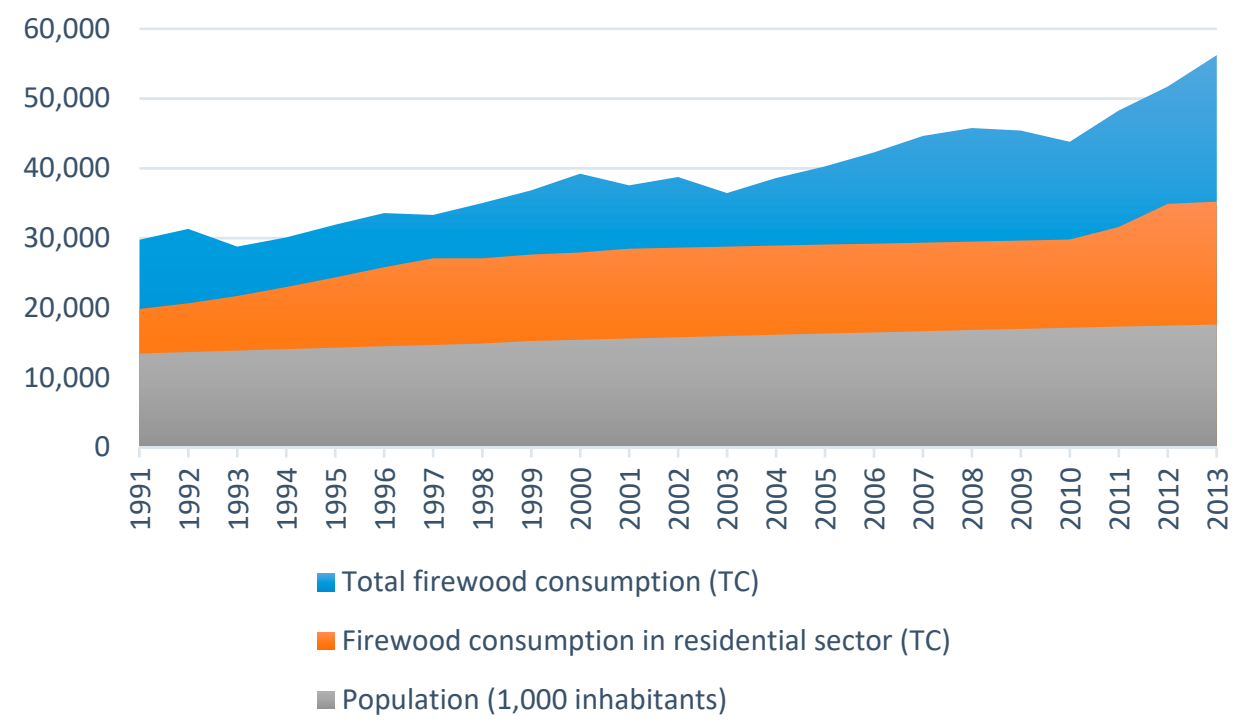

Figure 3. Firewood consumption and population [27].

The interactive tool GDB Compare was used to calculate the impact on health from suspended particles and pollution from fossil fuels [16]. GBD Compare is an interactive tool to analyze updated estimates of the world's health for 359 diseases and injuries and 84 risk factors from 1990 to 2017. The GBD Study 2017, coordinated by the Institute for Health Metrics and Evaluation [16], estimated the burden of diseases, injuries, and risk factors for 195 countries and territories, and at the subnational level for a subset of countries. Measures available include attributable deaths and disability-adjusted life years (DALYs) used in this paper. Annual population estimates by single year of age and sex for 1950-2017 are available at the IHME [44]. Annual specific fertility rate (ASFR) estimates by 5-year age groups in the 10-54 year range for 1950-2017 are available at the IHME [45]. Via the "Files" tab above, select tables published by GBD [46] are available for downloading in this record.

The data taken in this paper, corresponding to 2013, are differentiated by sex and risk factors. Two types of data are used: (i) the number of DALYs according to disease and risk factor and (ii) the number of deaths attributable to each risk factor.

The number of deaths and injuries caused by traffic accidents came from the police (called Carabineros) registries' annual report for 2013 [47]. The inflation rates in terms of variation of the Consumer Price Index, population data, and exchange rates were taken from the National Statistics Institute and the Central Bank of Chile, respectively.

The specific Chilean VSL came from the VSL value estimated [48] for 2010, adjusting the inflation rates and applying the purchasing power parity specified in this report. It was assumed that the specific value for Chile's VSL could be a proxy for the value of the most similar country in terms of PPP GDP per capita. This was Croatia [49,50], with a value of 2.07 million USD. This value has been updated as of 2013 and is considered representative for Temuco.

The housing data were provided by a statistical unit associated with the Ministry of Housing and Urban Planning [51] and the HDD data were provided by the meteorological network of Chile (METEORED) [52].

\section{Results}

Major findings are offered in the next two subsections. Firstly, monetary impacts on health were calculated following the two alternative approaches described in Section 2 (WTP and HCA). Then, the monetary savings from emissions avoided were also obtained. 


\subsection{Impacts on Health}

Following the WTP criteria approach through the VSL, total deaths in 2013 for males was 33.27 per 100,000 inhabitants with a range of 20.42-43.95 and 26.90 for females (15.54-36.94). The number of Temuco's inhabitants considered for 2013 was 265,101. The VSL value was taken from the WHO [48]. The VSL considered was 2.07 million USD 2010 per death. This value was updated as of 2013. It should be taken into account that only $51 \%$ of the impact on health from household air pollution from fossil fuels was considered due to the percentage of firewood consumption out of total energy consumption. Similarly, $88 \%$ of ambient particulate matter pollution impact on health was attributed to firewood combustion. The total monetary value of deaths for males was $13.7 \mathrm{M}$ (USD 2013) and 16.3 M (USD 2013) for females. The highest impact of ambient particulate matter pollution on health was that for chronic obstructive pulmonary disease in the case of males, 2.7 M (USD 2013). For females, the highest impact of ambient particulate matter pollution was for ischemic heart disease, 3.3 M (USD 2013). When focusing on household air pollution from fossil fuels, the highest impact for males also came from chronic obstructive pulmonary disease, $0.18 \mathrm{M}$ (USD 2013), and again ischemic heart disease for females 0.38M (USD 2013). Tables A4 and A5 in the appendix detail the results obtained.

When using the HCA approach, the monetary value of DALYs lost due to ambient particulate matter pollution and household air pollution from fossil fuels was estimated by multiplying the estimated DALYs associated with different diseases by GDP net health expenditures per capita (including current and capital expenditures) [26]. When using HCA criteria, the total DALYs attributed to these risk factors in 2013 was 11,605.71 per 100,000 inhabitants for males with a range of 10,631.65-12,755.12 and 7971.75 for females (7092.28-8966.85). The GDP per capita considered was 15,790 USD, while current health expenditure per capita was 1173 USD and capital health expenditure per capita was 43 USD. The total monetary value of total DALYs for males was 12.3 M (USD 2013) and 7 M (USD 2013) for females. Compared with the VSL approach, the results obtained differed mainly in the case of females. The highest impact of ambient particulate matter pollution on health was on ischemic heart disease, 3.3 M (USD 2013) for males and diabetes mellitus for females, 2.1 M (USD 2013). When we focused on household air pollution from fossil fuels, the highest impact also appeared to be from ischemic heart disease in the case of males $0.2 \mathrm{M}$ (USD 2013) and again from diabetes mellitus for females $0.2 \mathrm{M}$ (USD 2013). Tables A6 and A7 in the annex detail the results obtained.

To calculate the monetary value of accidents, we grouped victim data from police reports into three categories (fatalities, serious injuries, and minor injuries). Internal and external costs per death or injury [33] were converted into 2013 USD. The authors used Unidad de Fomento (UF) as their monetary unit. The UF is an accounting unit used in Chile. The exchange rate for 2013 was 1 UF equal to 23,309.56 CLP (Chilean currency). The official exchange rate of CLP to USD was used (495 CLP/USD). As police reports offer no detailed information for accidents in the city of Temuco, data was estimated following previous studies [53], from data corresponding to the region of Cautín, to which the city of Temuco belongs. The authors estimated that, for the case of Chile, $43 \%$ of fatalities, serious injuries, and minor injuries occurred in urban areas. For the rest of the accidents they estimated that $84 \%$ of total accidents occurred in urban areas. Table A8 in the annex shows the results. Based on interviews with traffic authorities, it was assumed that accidents caused due to smog were the result of particulate matter emission. Following our assumption, $88 \%$ was attributable to firewood combustion. The total monetary value of accidents attributable to particulate matter pollution was $76.7 \mathrm{M}$ (USD 2013) (72.3 M internal costs and $4.3 \mathrm{M}$ external costs).

\subsection{Monetary Savings from Emissions Avoided}

Table A9 shows the emission of pollutants and unfixed $\mathrm{CO}_{2}$ emissions due to logging for the use of eucalyptus firewood. Comparing the baseline scenario (Tables A4-A7) with the final scenario, as described in the methodology section, we obtained the reduction factors shown in Table 2. Higher values when considering $\mathrm{HDD} \leq 18^{\circ} \mathrm{C}$ derive from a reduction in firewood requirements. As Table A9 shows, the total number of $\mathrm{HDD} \leq 18^{\circ} \mathrm{C}$ was $17.64 \%$ higher than $\mathrm{HDD} \leq 15^{\circ} \mathrm{C}$. 
Table 2. Reduction factors of pollutant emissions (\%).

\begin{tabular}{|c|c|c|c|c|}
\hline & \multicolumn{2}{|c|}{$\mathrm{HDD} \leq 15^{\circ} \mathrm{C}$} & \multicolumn{2}{|c|}{$\mathrm{HDD} \leq 18^{\circ} \mathrm{C}$} \\
\hline & $\mathrm{CO}_{2}$ & Ambient Particulate & $\mathrm{CO}_{2}$ & Ambient Particulate \\
\hline $\begin{array}{c}\text { Emission reduction rate } \\
\text { without PV + storage } \\
\text { systems LCA }\end{array}$ & 40.49 & 40.31 & 47.63 & 47.42 \\
\hline $\begin{array}{c}\text { Emission reduction rate } \\
\text { with PV + storage } \\
\text { systems LCA }\end{array}$ & 38.46 & 40.31 & 45.25 & 47.42 \\
\hline
\end{tabular}

Source: Own elaboration.

From [39-41], it was assumed that the carbon footprint of the PV + storage system considered was equal to one year of total emissions avoided. Based on interviews with installation companies, it should be considered that most systems installed in Temuco are manufactured in China. The sea route considered was Shanghai-Valparaiso. The assumed useful life was 20 years. Our assumption was based on the meta-survey by [54].

This assumption was a conservative one as part of the literature cited by [54] considers a 30 year lifetime period. As ambient particulate matter is a local pollution problem (different from $\mathrm{CO}_{2}$, which impacts on global warming), LCA does not modify its reduction factors.

By applying the emission reduction rate to the monetary values of health impact and accidents, it was possible to identify the reductions of these costs derived from replacing wood burning stoves with PV + storage systems. These reductions are the benefits of the cost-benefit analysis carried out. Tables 3-6 show the results.

Table 3. Savings due to replacement of firewood with PV + storage systems without LCA. VSL criteria. Males and females. (USD 2013).

\begin{tabular}{|c|c|c|c|c|c|}
\hline & & \multicolumn{2}{|c|}{ Males } & \multicolumn{2}{|c|}{ Females } \\
\hline & & $\mathrm{HDD} \leq 15^{\circ} \mathrm{C}$ & $\mathrm{HDD} \leq 18^{\circ} \mathrm{C}$ & $\mathrm{HDD} \leq 15^{\circ} \mathrm{C}$ & $\mathrm{HDD} \leq 18^{\circ} \mathrm{C}$ \\
\hline \multirow{2}{*}{$\begin{array}{l}\text { Ischemic heart } \\
\text { disease }\end{array}$} & $\begin{array}{l}\text { Ambient particulate } \\
\text { matter pollution }\end{array}$ & $1,041,965$ & $1,773,615$ & $1,339,453$ & $2,279,994$ \\
\hline & $\begin{array}{l}\text { Household air pollution } \\
\text { from fossil fuels }\end{array}$ & 70,960 & 120,635 & 157,765 & 268,207 \\
\hline \multirow{2}{*}{ Stroke } & $\begin{array}{l}\text { Ambient particulate } \\
\text { matter pollution }\end{array}$ & 466,848 & 794,661 & 938,176 & $1,596,947$ \\
\hline & $\begin{array}{l}\text { Household air pollution } \\
\text { from fossil fuels }\end{array}$ & 59,883 & 101,804 & 110,231 & 187,397 \\
\hline \multirow{2}{*}{$\begin{array}{l}\text { Tracheobronchial } \\
\text { and lung cancer }\end{array}$} & $\begin{array}{l}\text { Ambient particulate } \\
\text { matter pollution }\end{array}$ & 686,884 & $1,169,202$ & 524,025 & 891,987 \\
\hline & $\begin{array}{l}\text { Household air pollution } \\
\text { from fossil fuels }\end{array}$ & 45,412 & 77,202 & 60,309 & 102,528 \\
\hline \multirow{2}{*}{$\begin{array}{l}\text { Lower } \\
\text { respiratory } \\
\text { infections }\end{array}$} & $\begin{array}{l}\text { Ambient particulate } \\
\text { matter pollution }\end{array}$ & $1,012,678$ & $1,723,762$ & $1,150,545$ & $1,958,438$ \\
\hline & $\begin{array}{l}\text { Household air pollution } \\
\text { from fossil fuels }\end{array}$ & 67,718 & 115,124 & 131,314 & 223,238 \\
\hline \multirow{2}{*}{$\begin{array}{c}\text { Chronic } \\
\text { obstructive } \\
\text { pulmonary } \\
\text { disease }\end{array}$} & $\begin{array}{l}\text { Ambient particulate } \\
\text { matter pollution }\end{array}$ & $1,127,226$ & $1,918,745$ & $1,022,607$ & $1,740,664$ \\
\hline & $\begin{array}{l}\text { Household air pollution } \\
\text { from fossil fuels }\end{array}$ & 75,703 & 128,697 & 118,935 & 202,195 \\
\hline \multirow{2}{*}{$\begin{array}{l}\text { Diabetes } \\
\text { mellitus }\end{array}$} & $\begin{array}{l}\text { Ambient particulate } \\
\text { matter pollution }\end{array}$ & 828,446 & $1,410,167$ & 934,796 & $1,591,194$ \\
\hline & $\begin{array}{l}\text { Household air pollution } \\
\text { from fossil fuels }\end{array}$ & 56,699 & 96,390 & 110,667 & 188,138 \\
\hline TOTAL & & $5,540,421$ & $9,430,005$ & $6,598,824$ & $11,230,928$ \\
\hline
\end{tabular}

Source: Own elaboration. 
Table 4. Savings due to replacement of firewood with PV + storage systems without LCA. HCA criteria, males and females, (USD 2013).

\begin{tabular}{|c|c|c|c|c|c|}
\hline & & \multicolumn{2}{|c|}{ Males } & \multicolumn{2}{|c|}{ Females } \\
\hline & & $\mathrm{HDD} \leq 15^{\circ} \mathrm{C}$ & $\mathrm{HDD} \leq 18^{\circ} \mathrm{C}$ & $\mathrm{HDD} \leq 15^{\circ} \mathrm{C}$ & $\mathrm{HDD} \leq 18^{\circ} \mathrm{C}$ \\
\hline \multirow{2}{*}{$\begin{array}{l}\text { Ischemic heart } \\
\text { disease }\end{array}$} & $\begin{array}{l}\text { Ambient particulate } \\
\text { matter pollution }\end{array}$ & $1,349,110$ & $2,296,432$ & 415,440 & 707,155 \\
\hline & $\begin{array}{l}\text { Household air pollution } \\
\text { from fossil fuels }\end{array}$ & 91,515 & 155,579 & 49,013 & 83,324 \\
\hline \multirow{2}{*}{ Stroke } & $\begin{array}{l}\text { Ambient particulate } \\
\text { matter pollution }\end{array}$ & 592,080 & $1,007,828$ & 364,386 & 620,251 \\
\hline & $\begin{array}{l}\text { Household air pollution } \\
\text { from fossil fuels }\end{array}$ & 40,342 & 68,583 & 42,816 & 72,789 \\
\hline \multirow{2}{*}{$\begin{array}{l}\text { Tracheobronchial } \\
\text { and lung cancer }\end{array}$} & $\begin{array}{l}\text { Ambient particulate } \\
\text { matter pollution }\end{array}$ & 389,811 & 663,530 & 193,608 & 329,556 \\
\hline & $\begin{array}{l}\text { Household air pollution } \\
\text { from fossil fuels }\end{array}$ & 25,809 & 43,877 & 22,230 & 37,791 \\
\hline \multirow{2}{*}{$\begin{array}{l}\text { Lower } \\
\text { respiratory } \\
\text { infections }\end{array}$} & $\begin{array}{l}\text { Ambient particulate } \\
\text { matter pollution }\end{array}$ & 479,522 & 816,234 & 263,050 & 447,759 \\
\hline & $\begin{array}{l}\text { Household air pollution } \\
\text { from fossil fuels }\end{array}$ & 33,584 & 57,093 & 29,307 & 49,823 \\
\hline \multirow{2}{*}{$\begin{array}{c}\text { Chronic } \\
\text { obstructive } \\
\text { pulmonary } \\
\text { disease }\end{array}$} & $\begin{array}{l}\text { Ambient particulate } \\
\text { matter pollution }\end{array}$ & 612,923 & $1,043,307$ & 454,521 & 773,677 \\
\hline & $\begin{array}{l}\text { Household air pollution } \\
\text { from fossil fuels }\end{array}$ & 41,067 & 69,816 & 52,890 & 89,916 \\
\hline \multirow{2}{*}{$\begin{array}{l}\text { Diabetes } \\
\text { mellitus }\end{array}$} & $\begin{array}{l}\text { Ambient particulate } \\
\text { matter pollution }\end{array}$ & $1,220,584$ & $2,077,658$ & 849,000 & $1,445,154$ \\
\hline & $\begin{array}{l}\text { Household air pollution } \\
\text { from fossil fuels }\end{array}$ & 83,427 & 141,829 & 100,518 & 170,884 \\
\hline TOTAL & & $4,959,774$ & $8,441,767$ & $2,836,778$ & $4,828,080$ \\
\hline
\end{tabular}

Source: Own elaboration.

Table 5. Savings due to replacement of firewood with PV + storage systems with LCA. VSL and HCA criteria, males and females, (USD 2013).

\begin{tabular}{cccccccc}
\hline \multicolumn{4}{c}{ HDD $\leq \mathbf{1 5}{ }^{\circ} \mathbf{C}$} & \multicolumn{3}{c}{ HDD $\leq \mathbf{1 8}{ }^{\circ} \mathbf{C}$} \\
\hline \multicolumn{2}{c}{ VSL } & \multicolumn{2}{c}{ HCA } & \multicolumn{2}{c}{ VSL } & \multicolumn{2}{c}{ HCA } \\
\hline Males & Females & Males & Females & Males & Females & Males & Females \\
\hline $5,442,841$ & $6,420,134$ & $4,877,914$ & $2,759,836$ & $9,378,902$ & $11,137,349$ & $8,398,896$ & $4,787,785$ \\
\hline
\end{tabular}

Table 6. Savings in traffic accidents due to replacement of firewood with PV + storage systems (USD 2013).

\begin{tabular}{ccccc}
\hline & \multicolumn{2}{c}{ HDD $\leq \mathbf{1 5}{ }^{\circ} \mathbf{C}$} & \multicolumn{2}{c}{ HDD $\leq \mathbf{1 8}{ }^{\circ} \mathbf{C}$} \\
\hline & Internal Costs & External Costs & Internal Costs & External Costs \\
\hline Fatalities & $3,270,279$ & 19,689 & $3,847,101$ & 23,162 \\
\hline Serious injuries & $20,021,697$ & 523,683 & $23,553,184$ & 616,052 \\
\hline Minor injuries & $5,888,907$ & $1,212,379$ & $6,927,610$ & $1,426,222$ \\
\hline Total & $29,180,883$ & $1,755,752$ & $34,327,895$ & $2,065,437$ \\
\hline
\end{tabular}


When HDD $\leq 15{ }^{\circ} \mathrm{C}$ was used as reference, the monetary value of the impact on health was reduced by 5.5 M USD 2013 for males and 6.5 M USD 2013 for females. When HDD $\leq 18{ }^{\circ} \mathrm{C}$ was used as a reference, these figures were 9.4 and 11.2 M USD 2013.

Taking into account HCA criteria, when $\mathrm{HDD} \leq 15^{\circ} \mathrm{C}$ was used as reference, the monetary value of the impact on health was reduced by 4.9 M USD 2013 for males and 2.8 M USD 2013 for females. When HDD $\leq 18^{\circ} \mathrm{C}$ was used as a reference, these were 8.4 and 4.8 M USD 2013.

When $\mathrm{CO}_{2}$ emissions in PV + storage systems LCA were considered, the results in Tables 3 and 4 must be reduced. Table 5 summarizes the major findings.

Finally, ambient particulate matter pollution prevented due to the replacement of firewood reduced traffic accidents and their corresponding monetary value. The details can be seen in Table 6 . When cool days were defined as $\leq 15^{\circ} \mathrm{C}$, total saving amounted to $30.93 \mathrm{M}$ USD 2013, while 36.38 represented total saving for the case of $\mathrm{HDD} \leq 18^{\circ} \mathrm{C}$. In this case, the database does not distinguish by sex; we assume males and females are equal.

When savings from reducing the impact of pollution on health and traffic accidents are compared with total costs of PV + storage purchases for homes between $51-70 \mathrm{~m}^{2}$, the benefits of replacing firewood for heating with this type of systems outweigh the total cost. The annualized total cost of PV + storage systems amounts to 8.76 M USD 2013. The benefits vary depending on the HDD definition, differing in a range between 2.7 M USD 2013 and 11.3 M USD 2013. As the savings from traffic accidents avoided vary in a range between 30.93 and 36.38 M USD 2013, both types of savings together outweigh the annual costs of such systems.

\section{Conclusions}

Replacing wood burning stoves in homes with PV + storage systems reduces the environmental stress as the decrease of firewood requirements allows a more sustainable model to reach a good standard of living. This replacement would also contribute to enhancing health levels in the six types of diseases under evaluation both for males and for females. Last but not least, the number of traffic accidents in a city like Temuco, which suffers from the thermal inversion phenomenon, would also be significantly reduced.

Our results support the positive measures included in the PM 2.5 Air Decontamination Plan, aimed at improving the thermal insulation of homes, the efficiency of wood burning stoves, and the improvement of the quality of firewood used. However, they enable a potential improvement if we take into account our recommendation to include the replacement of wood burning stoves with $\mathrm{PV}+$ storage systems-a situation that would generate an increase in positive environmental and health effects.

Given that the size of the savings obtained is significant, we recommend that funds then not required for health care be used to finance partial subsidies for the purchase of these systems, and also to improve the health care of different diseases and road safety. Temuco (like the other cities in the South-Central area of Chile) has high levels of energy poverty. This aspect strongly affects the adoption of technology by users. Public subsidies are a correct measure to bridge this barrier.

The study has not included the decreased cost due to the reduction of logging activities oriented to the production of firewood. In certain ways, this negative impact may be offset by the increased activity of the installation and maintenance sector for the new PV + storage systems. The cost of dismantling stoves was considered null or is compensated by the income from its possible sale as scrap. It should be also considered that many houses in Temuco still use the wood stove simultaneously to cook, heat the house, and generate sanitary hot water with water containers placed around the cannons. This is not included in the analysis. Further research might deal with these limits.

The monetary assessment of traffic accidents is also limited in the analysis by the fact that information on the number of accident victims in Chile is only available up to 24 hours after the accident. There are no records for injuries or fatalities that occur beyond that period of time. 
Another limit is derived from the fact that we assumed that smog was caused only by particulate matter emissions.

The results and conclusions obtained in this study have to be taken with caution. It has been assumed that the impact of pollution on health for the whole of Chile is the same for all cities. The GBD tool offers regional analysis for some countries, but not for Chile. This recommends taking the results as minimum values. It should also be borne in mind that the analysis focuses only on housing of 51 to $70 \mathrm{~m}^{2}$, with the possibility of extending it to housing with larger living areas. Further research might consider different operation conditions and managing stoves to spread out the set of firewood emission factors used.

Finally, it is important to point out that studies like this should delve deeper, taking into account that climate change, the growth of cities, and real estate development are resulting in more cities in Chile with pollution problems and saturation, which have highly damaging health effects. Thus, the search for new and better solutions to prevent the pollution produced by the heating of homes is a priority issue on the path to sustainable cities with a better quality of life.

Author Contributions: Idea conceiving and results obtained discussing: J.M.C.; conclusions writing: R.M., D.Q. and R.R.-C.; co-authoring: J.M.C., R.M., D.Q. and R.R.-C.

Funding: This research received no external funding.

Acknowledgments: The first and fourth authors acknowledge the funding received from the SEJ 132 project of the Andalusian Regional Government, the "Cátedra de Economía de la Energía y del Medio Ambiente, Red Eléctrica de España-Universidad de Sevilla" and are also grateful to the Spanish "Ministerio de Ciencia, Innovación y Universidades" for the financial support received from the research project (RTI2018-096725-B-I00). The authors acknowledge the funding provided by the Universidad Autónoma de Chile (Chile). The standard disclaimer applies.

Conflicts of Interest: The authors declare no conflict of interest. 


\section{Appendix A}

Table A1. Global radiation in Temuco. W/m². Average 2004-2016.

\begin{tabular}{|c|c|c|c|c|c|c|c|c|c|c|c|c|c|c|c|c|c|c|c|c|c|c|c|c|c|}
\hline & 00:00 to $23: 00$ & $0: 00$ & $1: 00$ & 2:00 & 3:00 & 4:00 & 5:00 & $6: 00$ & 7:00 & $8: 00$ & 9:00 & 10:00 & 11:00 & 12:00 & 13:00 & \begin{tabular}{l|}
$14: 00$ \\
\end{tabular} & \begin{tabular}{|l|}
$15: 00$ \\
\end{tabular} & |16:00 & 17:00 & 18:00 & \begin{tabular}{|l|}
$19: 00$ \\
\end{tabular} & $20: 00$ & 21:00 & 22:00 & 23:00 \\
\hline January & 282.4 & 0.0 & 0.0 & 0.0 & 0.0 & 0.0 & 0.0 & 10.4 & 52.2 & 205.3 & \begin{tabular}{|l|}
400.1 \\
\end{tabular} & 601.1 & 755.8 & 845.2 & 895.5 & $\begin{array}{l}863.5 \\
\end{array}$ & 768.1 & 637.7 & 446.4 & 237.2 & 49.5 & 9.3 & 0.0 & 0.0 & 0.0 \\
\hline February & 269.2 & 0.0 & 0.0 & 0.0 & 0.0 & 0.0 & 0.0 & 0.0 & 31.1 & \begin{tabular}{|l|}
167.5 \\
\end{tabular} & \begin{tabular}{|l|}
341.7 \\
\end{tabular} & 550.3 & 686.0 & 825.0 & \begin{tabular}{|l|}
879.5 \\
\end{tabular} & 860.4 & \begin{tabular}{|l|l|}
771.5 \\
\end{tabular} & \begin{tabular}{|l|}
630.6 \\
\end{tabular} & 446.7 & 228.0 & 43.2 & 0.0 & 0.0 & 0.0 & 0.0 \\
\hline March & 235.5 & 0.0 & 0.0 & 0.0 & 0.0 & 0.0 & 0.0 & 0.0 & 7.8 & \begin{tabular}{|l|}
201.8 \\
\end{tabular} & \begin{tabular}{|l|}
301.8 \\
\end{tabular} & 477.5 & 612.1 & \begin{tabular}{|l|}
728.4 \\
\end{tabular} & 785.0 & \begin{tabular}{|l|}
759.3 \\
\end{tabular} & \begin{tabular}{|l|}
664.1 \\
\end{tabular} & \begin{tabular}{|l|}
557.6 \\
\end{tabular} & \begin{tabular}{|l|}
367.3 \\
\end{tabular} & \begin{tabular}{|l|}
180.9 \\
\end{tabular} & 8.0 & 0.0 & 0.0 & 0.0 & 0.0 \\
\hline April & 172.5 & 0.0 & 0.0 & 0.0 & 0.0 & 0.0 & 0.0 & 0.0 & 0.0 & \begin{tabular}{|l|}
145.2 \\
\end{tabular} & \begin{tabular}{|l|}
200.4 \\
\end{tabular} & 343.4 & 465.8 & \begin{tabular}{|l|}
573.4 \\
\end{tabular} & |603.0 & \begin{tabular}{|l|}
595.0 \\
\end{tabular} & \begin{tabular}{|l|}
516.3 \\
\end{tabular} & \begin{tabular}{|l|l|}
409.6 \\
\end{tabular} & \begin{tabular}{|l|}
252.8 \\
\end{tabular} & \begin{tabular}{|l|l|}
35.4 \\
\end{tabular} & 0.0 & 0.0 & 0.0 & 0.0 & 0.0 \\
\hline May & 131.6 & 0.0 & 0.0 & 0.0 & 0.0 & 0.0 & 0.0 & 0.0 & 0.0 & 36.1 & \begin{tabular}{|l|}
278.8 \\
\end{tabular} & 255.8 & 342.2 & \begin{tabular}{|l|l|}
439.8 \\
\end{tabular} & 473.0 & \begin{tabular}{|l|}
440.2 \\
\end{tabular} & 368.1 & \begin{tabular}{|l|}
383.0 \\
\end{tabular} & \begin{tabular}{|l|}
141.9 \\
\end{tabular} & 0.0 & 0.0 & 0.0 & 0.0 & 0.0 & 0.0 \\
\hline June & 106.0 & 0.0 & 0.0 & 0.0 & 0.0 & 0.0 & 0.0 & 0.0 & 0.0 & 0.0 & \begin{tabular}{|l|}
241.9 \\
\end{tabular} & \begin{tabular}{|l|}
202.9 \\
\end{tabular} & \begin{tabular}{|l|}
275.6 \\
\end{tabular} & \begin{tabular}{|l|}
339.5 \\
\end{tabular} & \begin{tabular}{|l|}
383.6 \\
\end{tabular} & \begin{tabular}{|l|}
356.5 \\
\end{tabular} & \begin{tabular}{|l|}
296.8 \\
\end{tabular} & \begin{tabular}{|l|}
423.2 \\
\end{tabular} & 23.1 & 0.0 & 0.0 & 0.0 & 0.0 & 0.0 & $\overline{0.0}$ \\
\hline July & 114.5 & 0.0 & 0.0 & 0.0 & 0.0 & 0.0 & 0.0 & 0.0 & 0.0 & 0.1 & \begin{tabular}{|l|}
252.6 \\
\end{tabular} & 209.6 & 298.4 & 368.5 & \begin{tabular}{|l|}
393.8 \\
\end{tabular} & \begin{tabular}{|l|}
387.7 \\
\end{tabular} & \begin{tabular}{|l|}
324.9 \\
\end{tabular} & \begin{tabular}{|l|}
367.5 \\
\end{tabular} & \begin{tabular}{|l|}
146.1 \\
\end{tabular} & 0.0 & 0.0 & 0.0 & 0.0 & 0.0 & 0.0 \\
\hline August & 141.1 & 0.0 & 0.0 & 0.0 & 0.0 & 0.0 & 0.0 & 0.0 & 0.0 & \begin{tabular}{|l|l|}
78.7 \\
\end{tabular} & \begin{tabular}{|l|}
253.9 \\
\end{tabular} & 286.5 & \begin{tabular}{|l|}
372.6 \\
\end{tabular} & \begin{tabular}{|c|}
461.1 \\
\end{tabular} & \begin{tabular}{|l|}
489.0 \\
\end{tabular} & \begin{tabular}{|l|l|}
454.7 \\
\end{tabular} & \begin{tabular}{|l|}
387.0 \\
\end{tabular} & \begin{tabular}{|l|}
364.7 \\
\end{tabular} & \begin{tabular}{|l|}
229.2 \\
\end{tabular} & 7.9 & 0.0 & 0.0 & 0.0 & 0.0 & 0.0 \\
\hline September & 197.0 & 0.0 & 0.0 & 0.0 & 0.0 & 0.0 & 0.0 & 0.0 & 17.0 & 222.8 & \begin{tabular}{|l|}
339.2 \\
\end{tabular} & 426.9 & \begin{tabular}{|l|}
560.9 \\
\end{tabular} & \begin{tabular}{|l|}
616.5 \\
\end{tabular} & 640.0 & \begin{tabular}{|l|}
613.3 \\
\end{tabular} & \begin{tabular}{|l|}
530.6 \\
\end{tabular} & \begin{tabular}{|l|}
420.3 \\
\end{tabular} & \begin{tabular}{|l|}
247.1 \\
\end{tabular} & \begin{tabular}{|l|l|}
94.3 \\
\end{tabular} & 0.0 & 0.0 & 0.0 & 0.0 & 0.0 \\
\hline October & 212.4 & 0.0 & 0.0 & 0.0 & 0.0 & 0.0 & 0.0 & 2.4 & 79.6 & 200.9 & \begin{tabular}{|l|}
367.1 \\
\end{tabular} & 509.5 & 604.8 & 674.4 & \begin{tabular}{|l|l|}
695.4 \\
\end{tabular} & \begin{tabular}{|l|}
617.4 \\
\end{tabular} & \begin{tabular}{|l|}
516.9 \\
\end{tabular} & \begin{tabular}{|l|l|}
421.4 \\
\end{tabular} & 269.9 & 129.6 & 7.3 & 0.0 & 0.0 & 0.0 & 0.0 \\
\hline November & 237.2 & 0.0 & 0.0 & 0.0 & 0.0 & 0.0 & 0.0 & 23.3 & 96.1 & \begin{tabular}{|l|}
247.4 \\
\end{tabular} & \begin{tabular}{|l|l|}
419.7 \\
\end{tabular} & \begin{tabular}{|l|}
541.9 \\
\end{tabular} & \begin{tabular}{|l|}
627.3 \\
\end{tabular} & \begin{tabular}{|l|l|}
728.7 \\
\end{tabular} & \begin{tabular}{|l|}
745.8 \\
\end{tabular} & $\begin{array}{ll}696.9 \\
\end{array}$ & \begin{tabular}{|l|}
605.4 \\
\end{tabular} & \begin{tabular}{|l|}
475.6 \\
\end{tabular} & \begin{tabular}{|l|}
316.9 \\
\end{tabular} & \begin{tabular}{|l|}
135.0 \\
\end{tabular} & 31.5 & 0.0 & 0.0 & 0.0 & $\overline{0.0}$ \\
\hline December & 258.1 & 0.0 & 0.0 & 0.0 & 0.0 & 0.0 & 0.0 & 27.6 & 89.3 & 236.1 & \begin{tabular}{|l|l|}
404.4 \\
\end{tabular} & 563.1 & 686.8 & 784.3 & \begin{tabular}{|l|}
792.2 \\
\end{tabular} & 767.2 & \begin{tabular}{|l|l|}
675.4 \\
\end{tabular} & \begin{tabular}{|l|l|}
553.5 \\
\end{tabular} & \begin{tabular}{|l|}
375.6 \\
\end{tabular} & \begin{tabular}{|l|}
188.0 \\
\end{tabular} & 45.2 & 6.1 & 0.0 & 0.0 & 0.0 \\
\hline
\end{tabular}

Source: [55].

Table A2. Shadow due to topography in the city of Temuco. Average 2004-2016. $0=$ no shadow; $1=$ shadow.

\begin{tabular}{|c|c|c|c|c|c|c|c|c|c|c|c|c|c|c|c|c|c|c|c|c|c|c|c|c|c|}
\hline & $00: 00$ to $23: 00$ & $0: 00$ & 1:00 & 2:00 & $3: 00$ & $4: 00$ & $5: 00$ & $6: 00$ & $7: 00$ & $8: 00$ & 9:00 & 10:00 & 11:00 & 12:00 & 13:00 & 14:00 & $15: 00$ & $16: 00$ & 17:00 & \begin{tabular}{|l|}
$18: 00$ \\
\end{tabular} & \begin{tabular}{|l|}
$19: 00$ \\
\end{tabular} & 20:00 & 21:00 & \begin{tabular}{|l|}
$22: 00$ \\
\end{tabular} & \begin{tabular}{|l}
$23: 00$ \\
\end{tabular} \\
\hline $\begin{array}{c}\text { January } \\
\text { to } \\
\text { December }\end{array}$ & 0.5209 & 1 & 1 & 1 & 1 & 1 & 1 & 0.7595 & 0.4952 & 0.2067 & 0 & 0 & 0 & 0 & 0 & 0 & 0 & 0 & 0.1538 & 0.4006 & 0.5994 & 0.8861 & 1 & 1 & 1 \\
\hline January & 3965 & 1 & 1 & 1 & 1 & 1 & 1 & 0.3300 & 0 & 0 & 0 & 0 & 0 & 0 & 0 & 0 & 0 & 0 & 0 & 0 & 0 & 0.1861 & 1 & 1 & 1 \\
\hline February & 4583 & 1 & 1 & 1 & 1 & 1 & 1 & 1 & 0 & 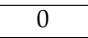 & 0 & 0 & 0 & 0 & 0 & 0 & 0 & 0 & 0 & , & 0 & 1 & 1 & 1 & 1 \\
\hline Marc & 5068 & 1 & 1 & 1 & 1 & 1 & 1 & 1 & 0.4615 & 0 & 0 & 0 & 0 & 0 & 0 & 0 & 0 & 0 & 0 & 0 & 0.7022 & 1 & 1 & 1 & 1 \\
\hline $\mathrm{Ap}$ & 5715 & 1 & 1 & 1 & 1 & 1 & 1 & 1 & 1 & 0 & 0 & 0 & 0 & 0 & 0 & 0 & 0 & 0 & 0 & 0.7179 & 1 & 1 & 1 & 1 & 1 \\
\hline May & 6169 & 1 & 1 & 1 & 1 & 1 & 1 & 1 & 1 & 0.3945 & 0 & 0 & 0 & 0 & 0 & 0 & 0 & 0 & 0.4119 & 1 & 1 & 1 & 1 & 1 & 1 \\
\hline June & 6666 & 1 & 1 & 1 & 1 & 1 & 1 & 1 & 1 & 1 & 0 & 0 & 0 & 0 & 0 & 0 & 0 & 0 & 1 & 1 & 1 & 1 & 1 & 1 & 1 \\
\hline $\mathrm{Ju}$ & 433 & 1 & 1 & 1 & 1 & 1 & 1 & 1 & 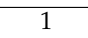 & 1 & 0 & 0 & 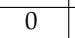 & 0 & 0 & 0 & 0 & 0 & 0.4342 & 1 & 1 & 1 & 1 & 1 & 1 \\
\hline August & 8869 & 1 & 1 & 1 & 1 & 1 & 1 & 1 & 1 & 0.0868 & 0 & 0 & 0 & 0 & 0 & 0 & 0 & 0 & 0 & 1 & 1 & 1 & 1 & 1 & 1 \\
\hline September & 38 & 1 & 1 & 1 & 1 & 1 & 1 & 1 & 0.4820 & 0 & 0 & 0 & 0 & 0 & 0 & 0 & 0 & 0 & 0 & \begin{tabular}{|l|l|}
0.0897 \\
\end{tabular} & 1 & 1 & 1 & 1 & 1 \\
\hline October & 699 & 1 & 1 & 1 & 1 & 1 & 1 & 0.7841 & 0 & 0 & 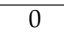 & 0 & 0 & 0 & 0 & 0 & 0 & 0 & 0 & 0 & 0.4913 & 1 & 1 & 1 & 1 \\
\hline November & .4166 & 1 & 1 & 1 & 1 & 1 & 1 & 0 & 0 & 0 & 0 & 0 & 0 & 0 & 0 & 0 & 0 & 0 & 0 & 0 & 0 & 1 & 1 & 1 & 1 \\
\hline December & 0.3936 & 1 & 1 & 1 & 1 & 1 & 1 & 0 & 0 & 0 & 0 & 0 & 0 & 0 & 0 & 0 & 0 & 0 & 0 & 0 & 0 & \begin{tabular}{|l|}
0.4472 \\
\end{tabular} & 1 & 1 & 1 \\
\hline
\end{tabular}

Source: [55]. 
Table A3. Presence of clouds in the city of Temuco. Average 2004-2016. $0=$ no clouds; $1=$ clouds.

\begin{tabular}{|c|c|c|c|c|c|c|c|c|c|c|c|c|c|c|c|c|c|c|c|c|c|c|c|c|c|}
\hline & $0: 00$ to $23: 00$ & $0: 00$ & 1:00 & $2: 00$ & 3:00 & 4:00 & 5:00 & 6:00 & $7: 00$ & $8: 00$ & 9:00 & \begin{tabular}{|l|}
$10: 00$ \\
\end{tabular} & 11:00 & 12:00 & 13:00 & 14:00 & 15:00 & $16: 00$ & \begin{tabular}{|l|}
$17: 00$ \\
\end{tabular} & \begin{tabular}{|l|}
$18: 00$ \\
\end{tabular} & 19:00 & $20: 00$ & $21: 00$ & $22: 00$ & $23: 00$ \\
\hline $\begin{array}{c}\text { January } \\
\text { to } \\
\text { December }\end{array}$ & 0.1844 & 0 & 0 & 0 & 0 & 0 & 0 & 0.0044 & $\mid 0.1395$ & 0.2176 & 0.3631 & 0.5399 & \begin{tabular}{|l|l|}
0.5390 \\
\end{tabular} & $\mid 0.5158$ & 0.4924 & $\mid 0.4824$ & \begin{tabular}{|l|l|}
0.4657 \\
\end{tabular} & 0.3059 & \begin{tabular}{|l|l|}
0.2331 \\
\end{tabular} & $\mid 0.1271$ & 0.0008 & \begin{tabular}{|l|} 
\\
\end{tabular} & 0 & 0 & 0 \\
\hline January & 0.1372 & 0 & 0 & 0 & 0 & 0 & 0 & 0.0099 & 0.3027 & 0.4640 & 0.3399 & 0.2804 & 0.2679 & \begin{tabular}{|l|l|}
0.2977 \\
\end{tabular} & 0.2704 & 0.2605 & 0.2332 & 0.2009 & 0.1786 & 0.1861 & 0 & 0 & 0 & 0 & 0 \\
\hline February & 0.1397 & 0 & 0 & 0 & 0 & 0 & 0 & 0 & 0.0163 & 0.4347 & 0.4510 & 0.3451 & \begin{tabular}{|l|l|}
0.3478 \\
\end{tabular} & 0.3070 & 0.2934 & \begin{tabular}{|l|l|}
0.2744 \\
\end{tabular} & 0.2445 & 0.2255 & \begin{tabular}{|l|}
0.1929 \\
\end{tabular} & 0.2201 & 0 & 0 & 0 & 0 & 0 \\
\hline March & 0.1460 & 0 & 0 & 0 & 0 & 0 & 0 & 0 & 0 & 0.0074 & 0.5037 & \begin{tabular}{|l|}
0.4491 \\
\end{tabular} & \begin{tabular}{|l|}
0.4416 \\
\end{tabular} & \begin{tabular}{|l|l|}
0.4094 \\
\end{tabular} & 0.7469 & \begin{tabular}{|l|}
0.3523 \\
\end{tabular} & \begin{tabular}{|l|}
0.3523 \\
\end{tabular} & 0.2804 & \begin{tabular}{|l|}
0.2655 \\
\end{tabular} & \begin{tabular}{|l|l|}
0.0694 \\
\end{tabular} & 0 & 0 & 0 & 0 & 0 \\
\hline April & & 0 & 0 & 0 & 0 & 0 & 0 & 0 & 0 & 0.0076 & 0.6692 & 0.6205 & 0.5923 & 0.5256 & 0.5102 & \begin{tabular}{|l|l|}
0.4666 \\
\end{tabular} & 0.4512 & 0.3974 & \begin{tabular}{|l|}
0.2923 \\
\end{tabular} & 0.0820 & & 0 & 0 & & 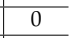 \\
\hline May & 0.1706 & 0 & 0 & 0 & 0 & 0 & 0 & 0 & 0 & 0 & 0.1612 & \begin{tabular}{|l|l|}
0.6823 \\
\end{tabular} & \begin{tabular}{|l|}
0.6873 \\
\end{tabular} & \begin{tabular}{|l|}
0.6129 \\
\end{tabular} & 0.5756 & \begin{tabular}{|l|}
0.5806 \\
\end{tabular} & \begin{tabular}{|l|}
0.5682 \\
\end{tabular} & \begin{tabular}{|l|l|}
0.2183 \\
\end{tabular} & \begin{tabular}{|l|}
0.0099 \\
\end{tabular} & 0 & 0 & 0 & 0 & 0 & 0 \\
\hline June & 808 & 0 & 0 & 0 & 0 & 0 & 0 & 0 & 0 & 0 & 0.0025 & \begin{tabular}{|l|l|}
0.6948 \\
\end{tabular} & 0.7256 & \begin{tabular}{|l|l|}
0.7076 \\
\end{tabular} & 0.6615 & \begin{tabular}{|l|}
0.6641 \\
\end{tabular} & \begin{tabular}{|l|}
0.643 \\
\end{tabular} & 0 & 0 & 0 & 0 & 0 & 0 & 0 & 0 \\
\hline July & & 0 & 0 & 0 & 0 & 0 & 0 & 0 & 0 & 0 & 0.0074 & \begin{tabular}{|l|}
0.7096 \\
\end{tabular} & \begin{tabular}{|l|}
0.7146 \\
\end{tabular} & \begin{tabular}{|l|l|}
0.6923 \\
\end{tabular} & 0.6749 & \begin{tabular}{|l|}
0.6451 \\
\end{tabular} & \begin{tabular}{|l|}
0.6426 \\
\end{tabular} & 0.2655 & \begin{tabular}{|l|}
0.0099 \\
\end{tabular} & 0 & 0 & 0 & 0 & 0 & 0 \\
\hline August & 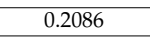 & 0 & 0 & 0 & 0 & 0 & 0 & 0 & 0 & 0 & 0.3325 & \begin{tabular}{|l|}
0.6625 \\
\end{tabular} & \begin{tabular}{|l|}
0.6774 \\
\end{tabular} & \begin{tabular}{|l|l|}
0.6277 \\
\end{tabular} & 0.6129 & \begin{tabular}{|l|}
0.6228 \\
\end{tabular} & \begin{tabular}{|l|l|}
0.6178 \\
\end{tabular} & \begin{tabular}{|l|l|} 
\\
\end{tabular} & \begin{tabular}{|l|}
0.2928 \\
\end{tabular} & \begin{tabular}{|l|l|}
0.1215 \\
\end{tabular} & & 0 & 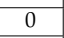 & & 0 \\
\hline September & 0 & 0 & 0 & 0 & 0 & 0 & 0 & 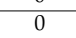 & \begin{tabular}{|l|}
0.0025 \\
\end{tabular} & 0.0256 & 0.4179 & \begin{tabular}{|l|}
0.5564 \\
\end{tabular} & \begin{tabular}{|l|}
0.5153 \\
\end{tabular} & \begin{tabular}{|l|}
0.5461 \\
\end{tabular} & 0.5230 & 0.5 & \begin{tabular}{|l|}
0.4794 \\
\end{tabular} & \begin{tabular}{|l|l|}
0.4487 \\
\end{tabular} & \begin{tabular}{|l|}
0.4461 \\
\end{tabular} & \begin{tabular}{|l|}
0.1051 \\
\end{tabular} & 0 & 0 & 0 & 0 & 0 \\
\hline October & & 0 & 0 & 0 & 0 & 0 & 0 & 0.0173 & \begin{tabular}{|l|l|}
0.2134 \\
\end{tabular} & 0.6005 & 0.5533 & \begin{tabular}{|l|l|}
0.5310 \\
\end{tabular} & \begin{tabular}{|l|l|}
0.5434 \\
\end{tabular} & \begin{tabular}{|l|}
0.5558 \\
\end{tabular} & 0.5310 & 0.5533 & \begin{tabular}{|l|l|}
0.5558 \\
\end{tabular} & \begin{tabular}{|l|l|}
0.4888 \\
\end{tabular} & \begin{tabular}{|l|}
0.4466 \\
\end{tabular} & \begin{tabular}{|l|l|}
0.0645 \\
\end{tabular} & 0 & 0 & 0 & 0 & 0 \\
\hline November & 0.2394 & 0 & 0 & 0 & 0 & 0 & 0 & 0.0205 & \begin{tabular}{|l|l|}
0.5794 \\
\end{tabular} & 0.5461 & 0.4666 & \begin{tabular}{|l|}
0.5153 \\
\end{tabular} & \begin{tabular}{|l|}
0.5282 \\
\end{tabular} & 0.5 & 0.4769 & \begin{tabular}{|l|}
0.4820 \\
\end{tabular} & \begin{tabular}{|l|}
0.4461 \\
\end{tabular} & \begin{tabular}{|l|l|}
0.4076 \\
\end{tabular} & 0.3820 & \begin{tabular}{|l|}
0.3948 \\
\end{tabular} & 0 & 0 & 0 & 0 & 0 \\
\hline December & 0.2012 & 0 & 0 & 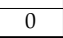 & 0 & 0 & 0 & 0.0050 & \begin{tabular}{|l|}
0.560 \\
\end{tabular} & 0.5251 & 0.4522 & 0.4321 & \begin{tabular}{|l|}
0.4271 \\
\end{tabular} & 0.4070 & 0.4045 & \begin{tabular}{|l|}
0.3869 \\
\end{tabular} & 0.3542 & 0.2989 & 0.2814 & 0.2814 & 0.0100 & 0.0025 & 0 & 0 & 0 \\
\hline
\end{tabular}
Source: [55].

Table A4. Monetary impact of ambient particulate matter pollution and household air pollution from fossil fuels on males following VSL criteria. Year 2013.

\begin{tabular}{|c|c|c|c|c|c|c|}
\hline & Total Deaths (\%) & Range (\%) & & $\begin{array}{l}\text { Risk Factor } \\
\text { Attribution }\end{array}$ & Range (\%) & $\begin{array}{l}\text { Weighted Monetary Value } \\
\text { of Deaths (USD 2013) }\end{array}$ \\
\hline \multirow{2}{*}{ Ischemic heart disease } & 11.88 & $11.49-12.33$ & Ambient particulate matter pollution & 12.48 & $8.35-15.38$ & $2,584,879$ \\
\hline & & & Household air pollution from fossil fuels & 1.46 & $0.7-2.77$ & 175,253 \\
\hline \multirow{2}{*}{ Stroke } & 8.43 & $8.09-8.82$ & Ambient particulate matter pollution & 7.88 & $4.86-10.41$ & $1,158,145$ \\
\hline & & & Household air pollution from fossil fuels & 0.86 & $0.39-1.66$ & 147,896 \\
\hline \multirow{2}{*}{$\begin{array}{l}\text { Tracheobronchial and } \\
\text { lung cancers }\end{array}$} & 3.57 & $3.44-3.72$ & Ambient particulate matter pollution & 13.56 & $6.3-20.99$ & $1,704,004$ \\
\hline & & & Household air pollution from fossil fuels & 1.54 & $0.69-2.94$ & 112,155 \\
\hline \multirow{2}{*}{$\begin{array}{l}\text { Lower respiratory } \\
\text { infections }\end{array}$} & 3.66 & $3.49-3.84$ & Ambient particulate matter pollution & 19.5 & $8.4-28.64$ & $2,512,224$ \\
\hline & & & Household air pollution from fossil fuels & 2.24 & $1.04-4.09$ & 167,247 \\
\hline \multirow{2}{*}{$\begin{array}{l}\text { Chronic obstructive } \\
\text { pulmonary disease }\end{array}$} & 3.9 & $3.58-4.33$ & Ambient particulate matter pollution & 20.37 & $9.55-30.46$ & $2,796,394$ \\
\hline & & & Household air pollution from fossil fuels & 2.35 & $0.93-4.68$ & 186,966 \\
\hline \multirow{2}{*}{ Diabetes mellitus } & 2.63 & $2.52-2.75$ & Ambient particulate matter pollution & 22.2 & $11.3-27.89$ & $2,055,187$ \\
\hline & & & Household air pollution from fossil fuels & 2.61 & $1.16-5.22$ & 140,032 \\
\hline Total & & & & & & $13,740,383$ \\
\hline
\end{tabular}

Source: Own elaboration from GBD [16]. 
Table A5. Monetary impact of ambient particulate matter pollution and household air pollution from fossil fuels on females following VSL criteria. Year 2013.

\begin{tabular}{|c|c|c|c|c|c|c|}
\hline & Total Deaths (\%) & Range (\%) & & $\begin{array}{l}\text { Risk Factor } \\
\text { Attribution }\end{array}$ & Range (\%) & $\begin{array}{l}\text { Weighted Monetary Value } \\
\text { of Deaths (USD 2013) }\end{array}$ \\
\hline \multirow{2}{*}{ Ischemic heart disease } & \multirow[t]{2}{*}{10} & \multirow[t]{2}{*}{$9.62-10.53$} & Ambient particulate matter pollution & 9.44 & $5.79-11.98$ & $3,322,880$ \\
\hline & & & Household air pollution from fossil fuels & 1.91 & $1-3.3$ & 389,640 \\
\hline \multirow[b]{2}{*}{ Stroke } & \multirow[t]{2}{*}{10.11} & \multirow[t]{2}{*}{$9.68-10.64$} & Ambient particulate matter pollution & 6.54 & $3.79-8.77$ & $2,327,403$ \\
\hline & & & Household air pollution from fossil fuels & 1.32 & $0.67-2.31$ & 272,242 \\
\hline \multirow{2}{*}{$\begin{array}{l}\text { Tracheobronchial and } \\
\text { lung cancers }\end{array}$} & \multirow[t]{2}{*}{2.83} & \multirow[t]{2}{*}{$2.71-2.95$} & Ambient particulate matter pollution & 13.05 & $5.9-20.32$ & $1,299,989$ \\
\hline & & & Household air pollution from fossil fuels & 2.58 & $1.23-4.63$ & 148,949 \\
\hline \multirow{2}{*}{$\begin{array}{l}\text { Lower respiratory } \\
\text { infections }\end{array}$} & \multirow{2}{*}{4.32} & \multirow{2}{*}{$4.12-4.53$} & Ambient particulate matter pollution & 18.77 & $8.28-27.83$ & $2,854,241$ \\
\hline & & & Household air pollution from fossil fuels & 3.68 & $1.84-6.37$ & 324,311 \\
\hline \multirow{2}{*}{$\begin{array}{l}\text { Chronic obstructive } \\
\text { pulmonary disease }\end{array}$} & \multirow[t]{2}{*}{3.74} & \multirow[t]{2}{*}{$3.41-4.52$} & Ambient particulate matter pollution & 19.27 & $8.63-28.8$ & $2,536,857$ \\
\hline & & & Household air pollution from fossil fuels & 3.85 & $1.73-6.94$ & 293,740 \\
\hline \multirow{2}{*}{ Diabetes mellitus } & \multirow[t]{2}{*}{3.08} & \multirow[t]{2}{*}{$2.94-3.22$} & Ambient particulate matter pollution & 21.39 & $10.96-27.56$ & $2,319,018$ \\
\hline & & & Household air pollution from fossil fuels & 4.35 & $2.04-7.91$ & 273,319 \\
\hline Total & & & & & & $16,362,589$ \\
\hline
\end{tabular}

Source: Own elaboration from GBD [16]

Table A6. Monetary impact of ambient particulate matter pollution and household air pollution from fossil fuels on males following HCA criteria. Year 2013.

\begin{tabular}{|c|c|c|c|c|c|c|}
\hline & Total DALYs (\%) & Range (\%) & & $\begin{array}{l}\text { Risk Factor } \\
\text { Attribution }\end{array}$ & Range (\%) & $\begin{array}{l}\text { Weighted Monetary Value } \\
\text { of Total DALYs (USD 2013) }\end{array}$ \\
\hline \multirow{2}{*}{ Ischemic heart disease } & 5.99 & $5.35-6.68$ & Ambient particulate matter pollution & 14.16 & $9.32-17.63$ & $3,346,837$ \\
\hline & & & Household air pollution from fossil fuels & 1.65 & $0.79-3.12$ & 226,018 \\
\hline \multirow{2}{*}{ Stroke } & 4.23 & $3.82-4.61$ & Ambient particulate matter pollution & 8.8 & $5.52-11.61$ & $1,468,817$ \\
\hline & & & Household air pollution from fossil fuels & 1.03 & $0.5-1.97$ & 99,634 \\
\hline \multirow{2}{*}{$\begin{array}{l}\text { Tracheobronchial and } \\
\text { lung cancers }\end{array}$} & 1.81 & $1.61-2.02$ & Ambient particulate matter pollution & 13.54 & $6.28-20.96$ & 967,034 \\
\hline & & & Household air pollution from fossil fuels & 1.54 & $0.68-2.93$ & 63,743 \\
\hline \multirow{2}{*}{$\begin{array}{l}\text { Lower respiratory } \\
\text { infections }\end{array}$} & 1.55 & $1.36-1.75$ & Ambient particulate matter pollution & 19.45 & $8.39-28.58$ & $1,189,586$ \\
\hline & & & Household air pollution from fossil fuels & 2.34 & $1.1-4.24$ & 82,943 \\
\hline \multirow{2}{*}{$\begin{array}{l}\text { Chronic obstructive } \\
\text { pulmonary disease }\end{array}$} & 1.92 & $1.68-2.19$ & Ambient particulate matter pollution & 20.07 & $9.41-29.96$ & $1,520,523$ \\
\hline & & & Household air pollution from fossil fuels & 2.31 & $0.92-4.62$ & 101,425 \\
\hline \multirow{2}{*}{ Diabetes mellitus } & 3.4 & $2.99-3.86$ & Ambient particulate matter pollution & 22.57 & $11.5-28.33$ & $3,027,994$ \\
\hline & & & Household air pollution from fossil fuels & 2.65 & $1.17-5.31$ & 206,043 \\
\hline Total & & & & & & $12,300,597$ \\
\hline
\end{tabular}

Source: Own elaboration from GBD [16]. 
Table A7. Monetary impact of ambient particulate matter pollution and household air pollution from fossil fuels on females following HCA criteria. Year 2013.

\begin{tabular}{|c|c|c|c|c|c|c|}
\hline & Total DALYs (\%) & Range (\%) & & $\begin{array}{l}\text { Risk Factor } \\
\text { Attribution }\end{array}$ & Range (\%) & $\begin{array}{l}\text { Weighted Monetary Value } \\
\text { of Total DALYs (USD 2013) }\end{array}$ \\
\hline \multirow{2}{*}{ Ischemic heart disease } & \multirow[t]{2}{*}{3.38} & \multirow[t]{2}{*}{$2.94-3.86$} & Ambient particulate matter pollution & 11.25 & $7.02-14.22$ & $1,030,613$ \\
\hline & & & Household air pollution from fossil fuels & 2.28 & $1.17-3.99$ & 121,050 \\
\hline \multirow{2}{*}{ Stroke } & \multirow[t]{2}{*}{4.4} & \multirow{2}{*}{$3.89-4.92$} & Ambient particulate matter pollution & 7.58 & $4.49-10.15$ & 903,958 \\
\hline & & & Household air pollution from fossil fuels & 1.53 & $0.78-2.66$ & 105,745 \\
\hline \multirow{2}{*}{$\begin{array}{l}\text { Tracheobronchial and } \\
\text { lung cancers }\end{array}$} & \multirow[t]{2}{*}{1.36} & \multirow[t]{2}{*}{$1.16-1.58$} & Ambient particulate matter pollution & 13.03 & $5.88-20.28$ & 480,297 \\
\hline & & & Household air pollution from fossil fuels & 2.57 & $1.23-4.61$ & 54,902 \\
\hline \multirow{2}{*}{$\begin{array}{l}\text { Lower respiratory } \\
\text { infections }\end{array}$} & \multirow[t]{2}{*}{1.28} & \multirow[t]{2}{*}{$1.1-1.5$} & Ambient particulate matter pollution & 18.81 & 8.29-27.87 & 652,567 \\
\hline & & & Household air pollution from fossil fuels & 3.6 & $1.8-6.19$ & 72,381 \\
\hline \multirow{2}{*}{$\begin{array}{l}\text { Chronic obstructive } \\
\text { pulmonary disease }\end{array}$} & \multirow[t]{2}{*}{2.2} & \multirow{2}{*}{$1.85-2.61$} & Ambient particulate matter pollution & 18.91 & $8.46-28.31$ & $1,127,563$ \\
\hline & & & Household air pollution from fossil fuels & 3.78 & $1.7-6.82$ & 130,626 \\
\hline \multirow{2}{*}{ Diabetes mellitus } & \multirow[t]{2}{*}{3.65} & \multirow[t]{2}{*}{$3.25-4.08$} & Ambient particulate matter pollution & 21.29 & $10.92-27.38$ & $2,106,178$ \\
\hline & & & Household air pollution from fossil fuels & 4.33 & $2.03-7.87$ & 248,253 \\
\hline Total & & & & & & $7,034,132$ \\
\hline
\end{tabular}

Source: Own elaboration from GBD [16]

Table A8. Monetary costs of traffic accidents caused by ambient particulate matters in Temuco.

\begin{tabular}{cccc}
\hline & Number & \multicolumn{2}{c}{ Weighted Costs USD 2013 } \\
\hline & & Internal costs & External costs \\
Fatalities & 33 & $8,112,823$ & 48,845 \\
Serious injuries & 515 & $49,669,305$ & $1,299,140$ \\
Minor injuries & 2180 & $14,609,047$ & $3,007,639$ \\
Total & 2728 & $72,391,175$ & $4,355,623$ \\
\hline
\end{tabular}

Source: Own elaboration from [47] 
Table A9. Total emissions and unfixed emissions due to firewood combustion per home in Temuco.

\begin{tabular}{|c|c|c|c|c|c|c|c|c|c|}
\hline \multirow[t]{2}{*}{ Surface $\mathrm{m}^{2}$} & \multirow[t]{2}{*}{ Number } & \multicolumn{2}{|c|}{$\begin{array}{l}\text { Firewood Requirements per } \\
\text { day (Kgs) }\end{array}$} & \multirow{2}{*}{$\begin{array}{c}\text { Total } \mathrm{CO}_{2} \\
\text { Emissions } \\
\text { from } \\
\text { Combustion } \\
\mathrm{HDD} \leq 15^{\circ} \mathrm{C} \\
\end{array}$} & \multirow{2}{*}{$\begin{array}{c}\text { Total } \mathrm{CO}_{2} \\
\text { Emissions } \\
\text { from } \\
\text { Combustion } \\
\mathrm{HDD} \leq 18^{\circ} \mathrm{C} \\
\end{array}$} & \multirow{2}{*}{$\begin{array}{c}\text { Total Unfixed } \\
\mathrm{CO}_{2} \\
\text { Emissions } \\
\mathrm{HDD} \leq 15^{\circ} \mathrm{C}\end{array}$} & \multirow{2}{*}{$\begin{array}{c}\text { Total Unfixed } \\
\mathrm{CO}_{2} \\
\text { Emissions } \\
\mathrm{HDD} \leq 18^{\circ} \mathrm{C}\end{array}$} & \multirow{2}{*}{$\begin{array}{c}\text { Total Particulate } \\
\text { Matters } \\
\text { Emissions from } \\
\text { Combustion } \\
\text { HDD } \leq 15^{\circ} \mathrm{C} \\
\end{array}$} & \multirow{2}{*}{$\begin{array}{c}\text { Total Particulate } \\
\text { Matters } \\
\text { Emissions from } \\
\text { Combustion } \\
\mathrm{HDD} \leq 18^{\circ} \mathrm{C} \\
\end{array}$} \\
\hline & & $\mathrm{HDD} \leq 15^{\circ} \mathrm{C}$ & $\mathrm{HDD} \leq 18^{\circ} \mathrm{C}$ & & & & & & \\
\hline $1-35$ & 5719 & 6.28 & 4.72 & $592,695,370$ & $927,393,932$ & $16,848,892$ & $26,363,561$ & $50,041,670$ & $78,300,495$ \\
\hline $36-50$ & 6656 & 6.61 & 4.72 & $689,811,912$ & $1,136,160,796$ & $19,609,680$ & $32,298,297$ & $58,241,285$ & $95,926,822$ \\
\hline $51-70$ & 12,388 & 8.97 & 5.98 & $1,626,125,618$ & $2,869,633,443$ & $46,226,809$ & $81,576,721$ & $137,294,882$ & $242,285,085$ \\
\hline $71-100$ & 2576 & 14.10 & 8.81 & $498,395,110$ & $938,155,502$ & $14,168,165$ & $26,669,486$ & $42,079,835$ & $79,209,101$ \\
\hline $101-140$ & 1461 & 19.27 & 11.33 & $363,433,336$ & $726,866,671$ & $10,331,529$ & $20,663,057$ & $30,684,921$ & $61,369,843$ \\
\hline$>140$ & 866 & 23.23 & 12.91 & $245,395,840$ & $519,661,779$ & $6,976,009$ & $14,772,724$ & $20,718,936$ & $43,875,394$ \\
\hline
\end{tabular}

(1) $\mathrm{CO}_{2}$ emission factor Eucalyptus firewood (grs $\mathrm{CO}_{2} / \mathrm{kg}$ ), 129.1. (2) Particulate matters Eucalyptus (grs $\left./ \mathrm{kg}\right), 3.67$. (3) Total annual $\mathrm{HDDs} \leq 15^{\circ} \mathrm{C}, 170 .(4)$ Total annual $\mathrm{HDDs} \leq 18{ }^{\circ} \mathrm{C}, 200$. Source: Own elaboration from $[34-37,40,51,56,57]$. 


\section{References}

1. Kausel, T.; Vegara, C. El Uso de la Leña Como Combustible en la IX Región. Aspectos Económicos. In Leña: Una Fuente Energética Renovable para Chile; Hernández, A., Lobos, M., Eds.; MIRA Ediciones: Valdivia, Chile, 2003; pp. 30-39.

2. Ministerio del Medio Ambiente. Plan de Descontaminación Atmosférica por mp2,5, para las Comunas de Temuco y Padre Las Casas Actualización del Plan de Descontaminación por mp10, para las Mismas Comunas; Ministerio del Medio Ambiente: Santiago, Chile, 2015; ISBN 0807695106.

3. Comisión Nacional de Energía. Balance Nacional de Energía 2013; Comisión Nacional de Energía: Santiago, Chile, 2014.

4. Cansino, J.M.; Moreno, R. Does forest matter regarding Chilean CO2 international abatement commitments? A multilevel decomposition approach. Carbon Manag. 2017, 9, 9-24. [CrossRef]

5. Smith, K.R. Health impacts of household fuelwood use in developing countries. Unasylva 2006, 57, 41-44.

6. Wielgosiński, G.; Łechtańska, P.; Namiecińska, O. Emission of some pollutants from biomass combustion in comparison to hard coal combustion. J. Energy Inst. 2017, 90, 787-796. [CrossRef]

7. Williams, A.; Jones, J.M.; Ma, L.; Pourkashanian, M. Pollutants from the combustion of solid biomass fuels. Prog. Energy Combust. Sci. 2012, 38, 113-137. [CrossRef]

8. Kim, K.H.; Kabir, E.; Kabir, S. A review on the human health impact of airborne particulate matter. Environ. Int. 2015, 74, 136-143. [CrossRef]

9. Pablo-Romero, M.d.P.; Román, R.; Limón, J.M.G.; Praena-Crespo, M. Effects of fine particles on children's hospital admissions for respiratory health in Seville, Spain. J. Air Waste Manag. Assoc. 2015, 65, 436-444. [CrossRef]

10. Román-Collado, R.; Jiménez de Reyna, J. The economic benefits of fulfilling the World Health Organization's limits for particulates: A case study in Algeciras Bay (Spain). J. Air Waste Manag. Assoc. 2019, 69, 438-449. [CrossRef]

11. Ministerio del Medio Ambiente. Planes de Descontaminacion Atmosférica. Estrategia 2014-2018. Available online: https://mma.gob.cl/wp-content/uploads/2014/08/articles-56174_Plan_LosLagos.pdf (accessed on 18 September 2019).

12. Ministerio de vivienda y Urbanismo. Resolución 793 Exenta. 2015. Available online: https://www.leychile.cl/ Navegar?idNorma=1076626 (accessed on 18 September 2019).

13. Ministerio de Medio Ambiente. Programa de Recambio de Calefactores. Available online: https://calefactores. mma.gob.cl/region/11 (accessed on 18 September 2019).

14. Armijo, G.; Whitman, C.; Roubelat, L. Reacondicionamiento térmico en Temuco-Padre las Casas, Chile: Una ciudad declarada saturada por contaminacion aérea. In Proceedings of the XII ENCAC-VIII ELACAC, Brasilia, Brazil, 25-27 September 2013.

15. Arcos-Vargas, A.; Cansino, J.M.; Román-Collado, R. Economic and environmental analysis of a residential PV system: A profitable contribution to the Paris agreement. Renew. Sustain. Energy Rev. 2018, 94, 1024-1035. [CrossRef]

16. Institute for Health Metrics and Evaluation GBD Compare Data Visualization. Available online: http: //www.healthdata.org/ (accessed on 18 September 2019).

17. COSMOPLAS Standard PV + storage system costs. Available online: https://www.cosmoplas.cl/energiasrenovables/ (accessed on 15 February 2019).

18. Kosmadakis, I.E.; Elmasides, C.; Eleftheriou, D.; Tsagarakis, K.P. A techno-economic analysis of a pv-battery system in Greece. Energies 2019, 12, 1357. [CrossRef]

19. Murray, C.J.L.; Lopez, A.D.; Jamison, D.T. The global burden of disease in 1990: Summary results, sensitivity analysis and future directions. Bull. World Health Organ. 1994.

20. Murray, C.; Lopez, A. Global Health Statistics: A Compendium of Incidence, Prevalence, and Mortality Estimates for Over 200 Conditions; Harvard School of Public Health: Boston, MA, USA, 1996.

21. Murray, C.J.; Lopez, A.D. A comprehensive assessment of mortality and disability from disease, injures and risk factors in 1990 and projected to 2020. In The Global Burden of Disease; Harvard School of Public Health: Boston, MA, USA, 1996.

22. Murray, C.J.L.; Lopez, A.D. Regional-patterns of disability-free life expectancy and disability-adjusted life expectancy: Global Burden of Disease Study. Lancet 1997, 72, 495-509. [CrossRef] 
23. Murray, C.J.L.; Acharya, A.K. Understanding DALYs. J. Health. Econ. 1997, 16, 703-730. [CrossRef]

24. Oostvogels, A.J.J.M.; De Wit, G.A.; Jahn, B.; Cassini, A.; Colzani, E.; De Waure, C.; Kretzschmar, M.E.E.; Siebert, U.; Mühlberger, N.; Mangen, M.J.J. Use of DALYs in economic analyses on interventions for infectious diseases: A systematic review. Epidemiol. Infect. 2015, 143, 1791-1802. [CrossRef] [PubMed]

25. Murray, C.J.L. Quantifying the burden of disease: The technical basis for disability-adjusted life years. Bull. World Health Organ. 1994, 72, 429-445. [PubMed]

26. Kirigia, J.M.; Mwabu, G.M. The Monetary Value of Disability-Adjusted-Life-Years Lost in the East African Community in 2015. Mod. Econ. 2018, 09, 1360-1377. [CrossRef]

27. WHO. World Health Statistics 2017: Monitoring Health for The Sustainable Development Goals; WHO: Geneva, Switzerland, 2017; ISBN 978-92-4-156548-6.

28. Hall, J.V.; Brajer, V.; Lurmann, F.W. The Health and Related Economic Benefits of Attaining Healthful Air in the San Joaquin Valley. Available online: http://www.scientificintegrityinstitute.org/Hall032906.pdf (accessed on 18 September 2019).

29. Dalal, K.; Svanström, L. Economic Burden of Disability Adjusted Life Years (DALYs) of Injuries. Health 2015, 07, 487-494. [CrossRef]

30. Romero, N. Consumo de Energía a Nivel Residencial en Chile y Análisis de Eficiencia Energética en Calefacción. Bachelor's Thesis, Universidad de Chile, Santiago, Chile, 2011.

31. Burschel, H.; Hernández, A.; Lobos, M. Leña: Una fuente energética renovable para Chile; Editorial: Santiago, Chile, 2003.

32. Rizzi, L.I. Diseño de Instrumentos Económicos para la Internalización de Externalidades de Accidentes de Tránsito. Cuad. Econ. 2005, 42, 126. [CrossRef]

33. Reyes, A. Medición de la externalidad negativa de accidentes de tránsito asociados al consumo de alcohol. Bachelor's Thesis, Universidad de Chile, Santiago, Chile, 2016.

34. SICAM. Actualización del Inventario de Emisiones Atmosféricas de las Comunas de Temuco y Padre Las Casas, Año Base 2013; SICAM: Temuco, Chile, 2014.

35. Ministerio de Energía. Medición del Consumo Nacional de Leña y Otros Combustibles Sólidos Derivados de la Madera; Ministerio de Energía: Santiago, Chile, 2015.

36. Espina, A. Densidad básica de la madera de Eucalyptus globulus en dos sitios en Chile. Bachelor's Thesis, Universidad Austral de Chile, Valdivia, Chile, 2006.

37. Ministerio de Energía. Infografía de la Leña; Ministerio de Energía: Santiago, Chile, 2018.

38. Masera Cerutti, O.; Coralli, F.; García Bustamante, C. La Bioenergía en México: Situación Actual y Perspectivas. Red Mex. Energ. 2011, 22, 118-125.

39. Ministerio del Medio Ambiente. Inventario Nacional de Gases de Efecto Invernadero de Chile; Ministerio del Medio Ambiente: Santiago, Chile, 2017.

40. Corporación Nacional Forestal. Caracterización de Centros de Acopio Rurales y Periurbanos de Leña en las Regiones de O’Higgins, Maule, Bío-Bío, La Araucanía, Los Ríos, Los Lagos y Aysen; Corporación Nacional Forestal: Santiago, Chile, 2015.

41. Raugei, M.; Frankl, P. Life cycle impacts and costs of photovoltaic systems: Current state of the art and future outlooks. Energy 2009, 34, 392-399. [CrossRef]

42. De Wild-Scholten, M.J. Energy payback time and carbon footprint of commercial photovoltaic systems. Sol. Energy Mater. Sol. Cells 2013, 119, 296-305. [CrossRef]

43. Frischknecht, R.; Itten, R.; Sinha, P.; de Wild-Scholten, M.; Zhang, J.; Fthenakis, V.; Kim, H.C.; Raugei, M.; Stucki, M. Life Cycle Inventories and Life Cycle Assessments of Photovoltaic Systems; PVPS Task 12, Report T12-04:2015; IEA: Paris, France, 2015.

44. Institute for Health Metrics and Evaluation. Global Burden of Disease Study 2017 (GBD 2017) Population Estimates 1950-2017. Available online: http://ghdx.healthdata.org/record/ihme-data/gbd-2017-populationestimates-1950-2017 (accessed on 20 September 2019).

45. Institute for Health Metrics and Evaluation. Global Burden of Disease Study 2017 (GBD 2017) Fertility Estimates 1950-2017. Available online: http://ghdx.healthdata.org/record/ihme-data/gbd-2017-fertilityestimates-1950-2017 (accessed on 20 September 2019).

46. GBD. Population and Fertility Collaborators. Population and fertility by age and sex for 195 countries and territories, 1950-2017: A systematic analysis for the Global Burden of Disease Study 2017. Lancet 2019, 392, 1995-2051. 
47. Instituto Nacional de Estadísticas. Informe Anual Carabineros 2013; Instituto Nacional de Estadísticas: Santiago, Chile, 2013; ISBN 9789563231489.

48. WHO Regional Office for Europe; OECD. Economic Cost of the Health Impact of Air Pollution in Europe: Clean Air, Health and Wealth; WHO: Geneva, Switzerland, 2015.

49. International Monetary Fund. World Economic Outlook Database. April 2018. Report for Selected Countries and Subjects. Available online: http://www.imf.org/external/pubs/ft/weo/2018/01/weodata/weorept.aspx? sy $=1995 \&$ ey $=2023 \&$ ssm $=1 \&$ scsm $=1 \&$ ssd $=1 \&$ sort $=$ country \&ds $=. \& b r=1 \& p r 1 . x=85 \& p r 1 . y=12 \& c=199 \%$ 2C534\%2C111\&s=NGDP_R\%2CNGDP_RPCH\%2CNGDP\%2CNGDPD\%2CPPPGDP\%2CNGDP_D\% 2CNGDPRPC\%2CNGDPRPPPPC\%2CNGDPPC\%2CNGDP (accessed on 18 September 2019).

50. World Bank. World Development Indicators Database. Available online: https://databank.worldbank.org/ source/world-development-indicators (accessed on 18 September 2019).

51. Observatorio Urbano. PE Viviendas Unidades y Superficie Según Año y Comuna 2002 a November 2018; Ministerio de Vivienda y Urbanismo: Santiago, Chile, 2018.

52. Reportes de Datos Climaticos de Chile. Meteored. Available online: https://www.meteored.cl/tiempo-en Temuco-America+Sur-Chile-Araucania-SCTC-sactual-18267.html (accessed on 18 September 2019).

53. Gazmuri, P.; Muñoz, J.C.; Rizzi, L.I.; Fresard, F.; Cumsille, S. Reducción de la mortalidad por accidentes del tránsito en Chile: 10 medidas prioritarias. In Camino al Bicentenario Doce Propuestas para Chile; Pontificia Universidad Catolica de Chile: Santiago, Chile, 2006; pp. 357-386. ISBN 9781604138795.

54. Nugent, D.; Sovacool, B.K. Assessing the lifecycle greenhouse gas emissions from solar PV and wind energy: A critical meta-survey. Energy Policy 2014, 65, 229-244. [CrossRef]

55. Ministerio de Energía. Explorador Solar DGF-Min. Energía: Base de Datos Sobre Radiación Solar en Chile; Ministerio de Energía: Santiago, Chile, 2019.

56. Gomez-Lobo, A.; Lima, J.L.; Hill, C.; Meneses, M. Diagnóstico del Mercado de la Leña en Chile; Informe Final; Comisión Nacional de Energía: Santiago, Chile, 2006.

57. BizEE Software Limited. Custom Degree Day Data. Available online: https://www.degreedays.net/ (accessed on 18 September 2019).

(C) 2019 by the authors. Licensee MDPI, Basel, Switzerland. This article is an open access article distributed under the terms and conditions of the Creative Commons Attribution (CC BY) license (http://creativecommons.org/licenses/by/4.0/). 